\title{
Linguaggi architettonici tra presente e passato: la borgata giardino del Pigneto
}

\author{
Marco Canciani \\ Francesca Romana Stabile \\ Valentina Apostoli
}

Abstract

La pandemia, dovuta al COVID- 19 ha avuto effetti devastanti in tutti i settori, politici, sociali e culturali. Ciononostante, nell'ambito della ricerca scientifica, il rinnovato interesse per lo sviluppo di linguaggi analitici e interdisciplinari, la riduzione di distanze non solo fisiche ma anche intellettuali attraverso le connessioni telematiche, l'ottimizzazione delle tecnologie digitali e multimediali, hanno prodotto un nuovo impulso nei campi della ricerca e della sperimentazione. Scopo dello studio che qui presentiamo, relativo alla borgata giardino del Pigneto, nel quadrante Est di Roma, è quello di fornire una lettura trasversale del tessuto urbano, grazie a una ricerca interdisciplinare che si confronta con la necessità di interazione scientifica che attraversa la situazione contingente. La borgata giardino è stata analizzata allo stato attuale in rapporto alle ipotesi progettuali del 1920-1921 e alla sua consistenza edilizia degli anni Sessanta, quando la storia del Pigneto si annoda con quella del film Accattone di Pier Paolo Pasolini. In alcune scene del film, i villini della borgata giardino fanno da sfondo alle riprese del film, producendo immagini, ricche di possibili suggestioni e rimandi. Rimangono oggi diverse testimonianze della città giardino, espressioni di un linguaggio architettonico chiaramente definito e riconoscibile, a cui si sommano, però, addizioni e trasformazioni, molto spesso incoerenti.

\section{Parole chiave}

Roma, Pigneto, borgata giardino, linguaggio architettonico, rilievo urbano e architettonico.

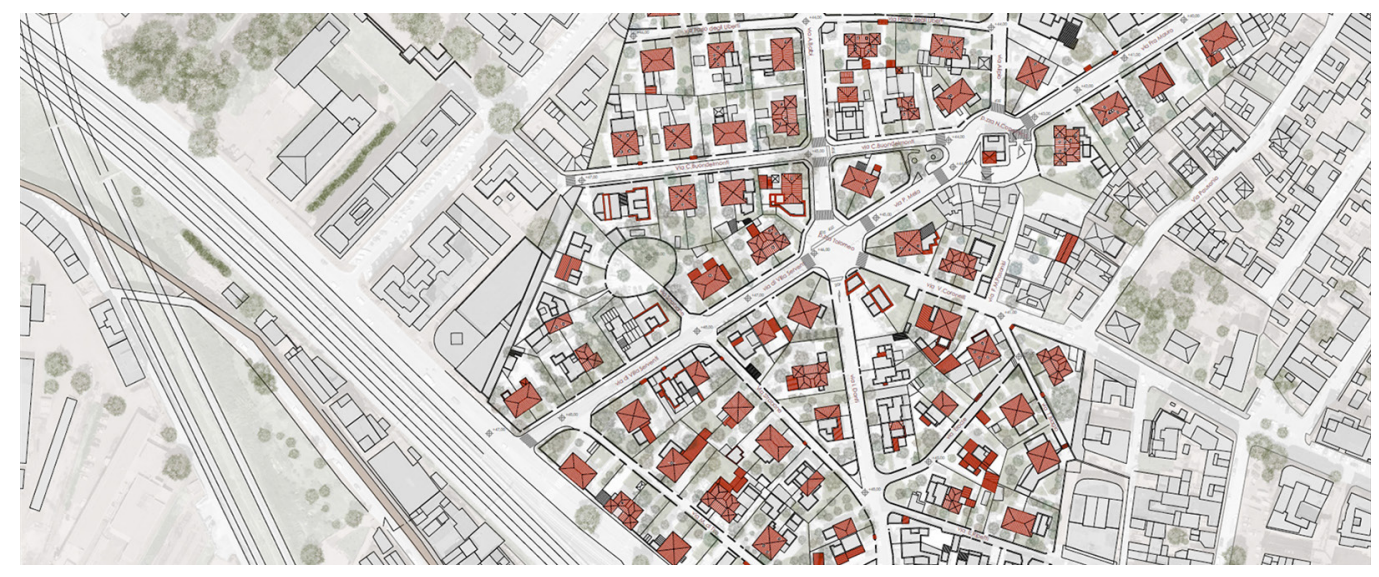




\section{Introduzione}

Lo stato di segregazione e isolamento, generato dalla pandemia, dovuta al COVID-19, che in quest'ultimo anno ha avuto effetti devastanti sotto vari punti di vista e in tutti i settori, politici, sociali e culturali, ha generato nella comunità scientifica, da una parte, un profondo senso di stasi e di allontanamento dagli ambiti applicativi, e, d'altra parte, un rinnovato interesse nello sviluppo di tecnologie digitali e multimediali e di nuovi linguaggi analitici, in grado d'integrare competenze pluridisciplinari e di ridurre le distanze, non solo fisiche, attraverso le sedute telematiche, ma anche intellettuali. Lo studio, di cui presentiamo una prima sintesi, riguarda l'analisi di un ambito urbano, la borgata giardino nel quartiere Pigneto, con lo scopo di comprenderne i caratteri insediativi, tipologici e architettonici, secondo una lettura su più livelli [Brunori, Cretarola, Zampilli 20 I6, p. 42]. Tale ricerca, che ha avuto come primo esito una tesi di laurea Magistrale [Apostoli 20 I9-2020], s'inserisce in un filone, portato avanti da diversi anni e orientato all'analisi di contesti urbani minori e della periferia storica romana [Canciani et al. 2019; Stabile 2019], che vede l'apporto e l'interazione di diverse discipline, Disegno, Storia e Restauro, in modo da avere una lettura multiforme e multilivello, a partire dallo studio alla scala urbana, sino a quella dell'edificio. La metodologia utilizzata ha previsto una prima fase di acquisizione dei dati di rilievo del tessuto urbano, che è stata eseguita tramite una procedura 'a distanza', utilizzando un modello 3D derivato dalle immagini acquisite dall'applicazione Google Earth [I] (fig. I), attraverso la quale è stato possibile effettuare il confronto tra una planimetria di riferimento dello stato attuale e le varie planimetrie storiche (come, ad esempio, le aree soggette ai bombardamenti del 1943-1944), così da comprendere le trasformazioni avvenute nel tempo (fig. 2).

Fig. I.Vista assonometrica del modello ottenuto dalle immagini estratte da Google Earth della borgata giardino. In evidenza l'omogeneità dei villini nel tessuto urbano e le strade principali che s'incrociano su piazza sincrociano su piazza (clone Canciani).

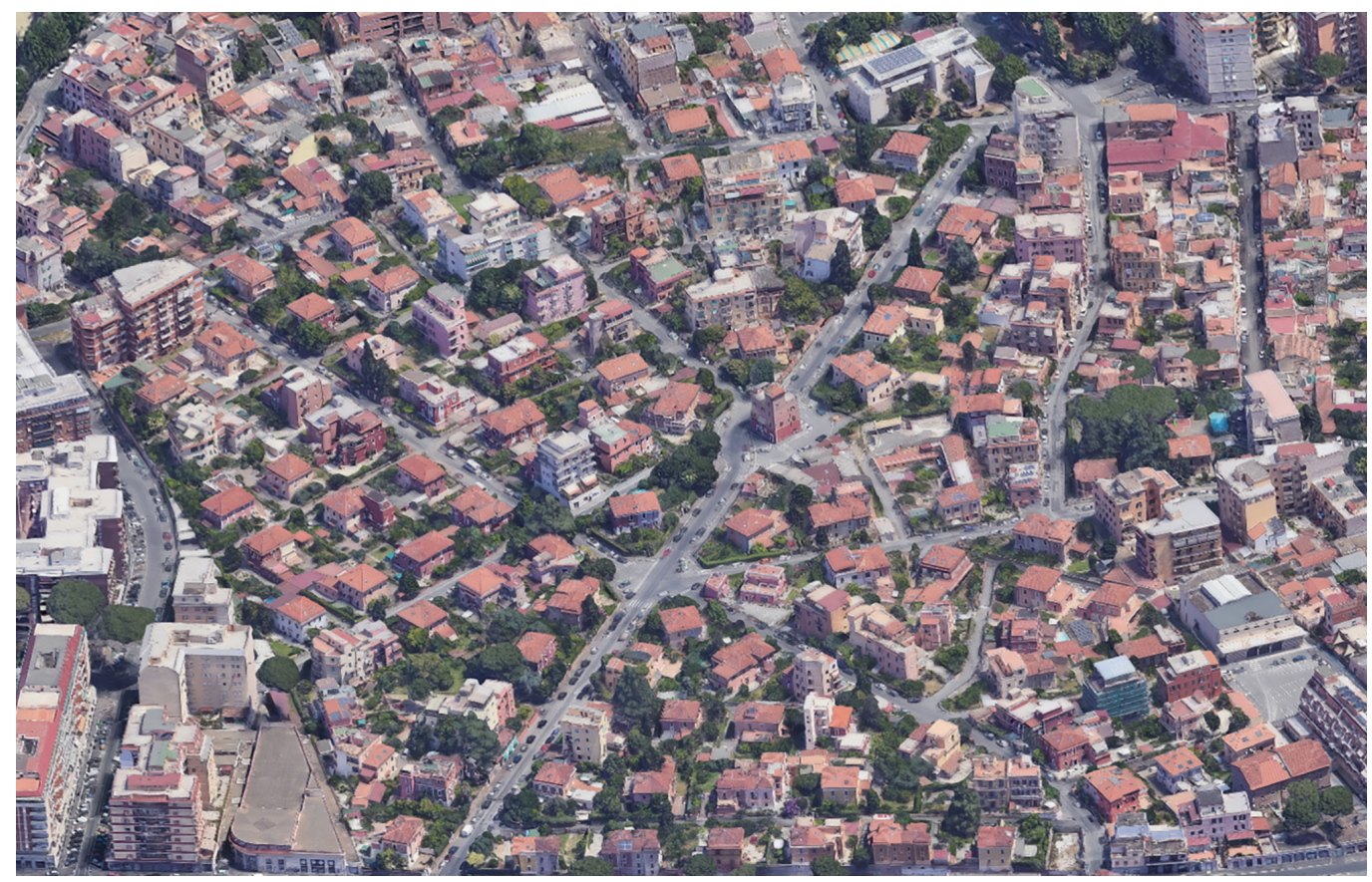

\section{Il Pigneto dagli anni Sessanta a oggi}

Colpito duramente dai bombardamenti del 1943 e del 1944, il Pigneto, descritto da Pier Paolo Pasolini nel film Accattone [2], all'inizio degli anni Sessanta apparteneva a "una Roma che non era Roma, cresciuto in maniera disordinata, in un susseguirsi di impalcature e casamenti in costruzione, e grandi prati, depositi di rottami, terreni fabbricabili" [Pasolini 1955 , p. 85]. Con la massiccia immigrazione dal Centro e dal Sud Italia, il Pigneto rappresentava "la casa del sottoproletariato, dei poveri manovali a giornata, mentre, a due strade da lì, fer- 


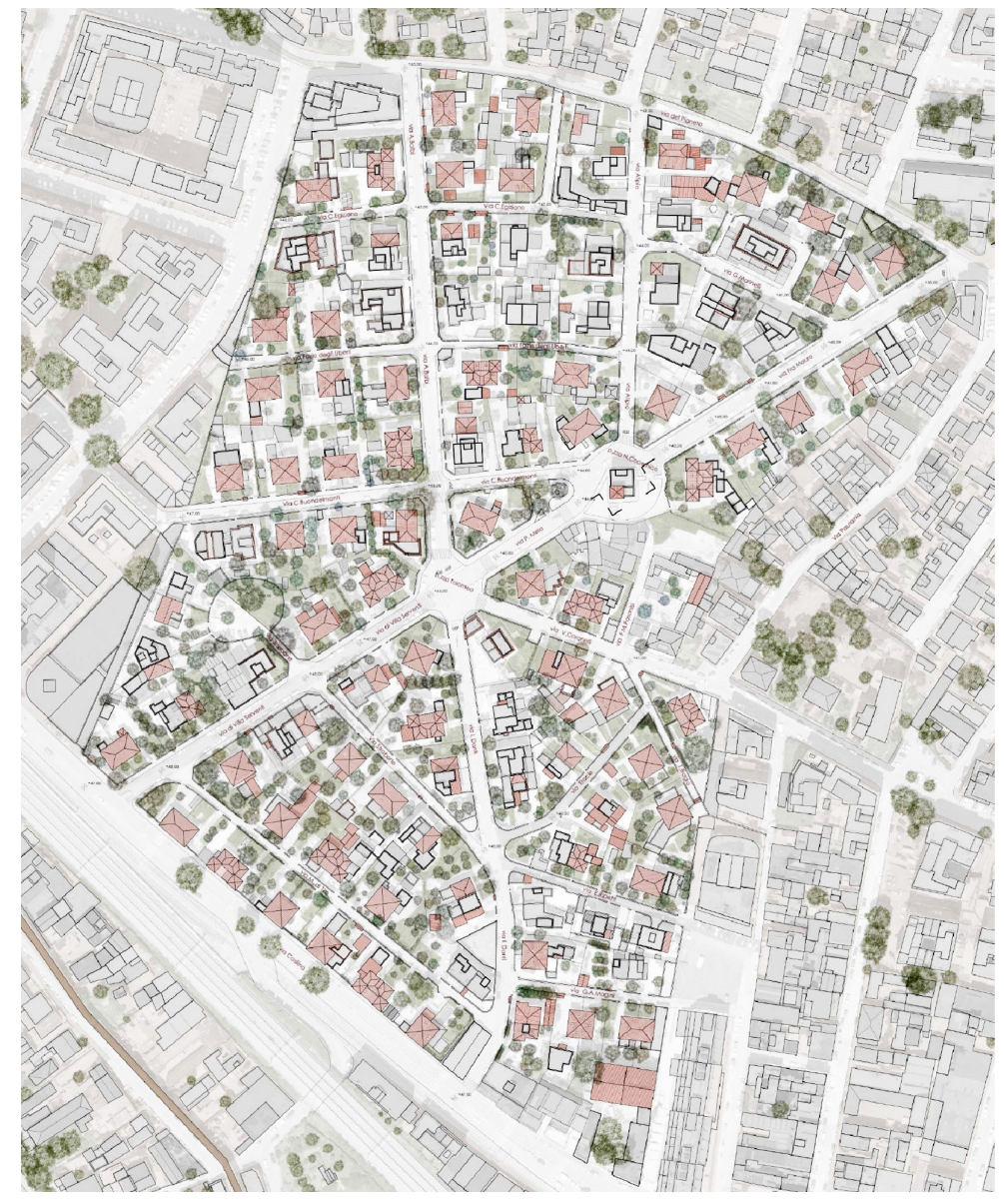

rovieri e operai avevano case dignitose" [Magliaro 20I4] [3]. Nell'immagine, tratta dal film (fig. 3), è evidente la stridente contrapposizione tra le baracche della borgata e i villini della "Cooperativa Termini fra i ferrovieri", che rappresentava un'enclave autonoma, racchiusa in un comparto a sé, tra via del Pigneto, via Casilina, via De Agostini e via Pausania.

Tra gli anni Sessanta e Novanta, l'intera area a Est di Roma, sulla spinta del Piano regolatore generale del 1962, vede una notevole espansione, con la costruzione della Tangenziale Est, a supporto del programmato Sistema Direzionale Orientale, e di diversi nuclei edilizi di tipo intensivo. Anche le aree perimetrali del Pigneto sono investite da un processo di ricostruzione e sostituzione con palazzine ma, attraverso la variante del PRG del 1967, la zona della borgata giardino della Cooperativa Termini viene a essere preservata dalla speculazione edilizia, classificata come zona B di conservazione del tessuto edilizio [4] (solo alcune palazzine intensive vengono a essere realizzate nell'area). Nella stessa direzione si muove il programma di riqualificazione del 1988, che investe direttamente anche la Cooperativa Termini. Dal 2000 fino a oggi, il Pigneto, infatti, è segnato da un processo di profonda trasformazione e riqualificazione del tessuto urbano, sociale e edilizio, grazie alle iniziative dell'Amministrazione comunale e municipale (come la costruzione della stazione della Metro e l'istituzione dell'isola pedonale su via del Pigneto nel 20I5), divenendo un quartiere più vivibile e un importante polo artistico, culturale e ricreativo della città, connotato dalla Street Art e dalla vivace movida romana. Allo stesso tempo, il fenomeno della 'gentrificazione' [5] ha portato le abitazioni a svuotarsi dai vecchi proprietari, perdendo così quel carattere di autenticità popolare, esaltato da Pasolini nelle sue opere. La borgata giardino del Pigneto, ancora una volta, sembra essere estranea a questo fenomeno, anche se l'eco delle manifestazioni artistiche e culturali arriva al suo interno: sui muri e le saracinesche campeggiano alcuni murales, animando e contaminando il paesaggio dei villini degli anni Venti (fig. 4). 
Fig. 3. Pier Paolo Pasolini, Accattone, 1961. Fotogramma tratto dal film in cui s'intravede una baracca e, sullo sfondo, un villino, sullo stondo, alla borgata giardino.
Fig. 4. Alcuni murales nella borgata giardino dintorni: a) via Alipio; b) via Pausania; c e d) via Adriano Balbi (foto di V.Apostoli).

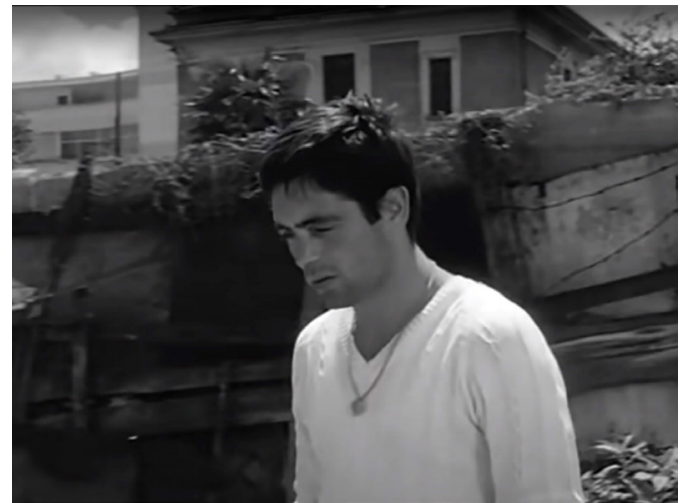

La borgata giardino del Pigneto: il contesto storico e la Cooperativa Termini, 1919-1930

II progetto della borgata giardino al Pigneto si inquadra nella politica nazionale a sostegno dell'attività edilizia del primo dopoguerra. Con il Regio decreto-legge n. 23 I 8 del 30 novembre 1919, Testo unico per le case popolari ed economiche e per l'industria edilizia, si assicuravano una serie di norme e incentivi finanziari per la Capitale.

La legge permetteva di stipulare mutui anche alle cooperative private fino all'ammontare complessivo del costo del terreno e delle costruzioni, nel rispetto di condizioni e criteri fissati dal Comitato Centrale Edilizio, istituito con l'art. 58 del Testo Unico.

Nel novembre del 1919 una relazione a firma di Gustavo Giovannoni, per il Comitato Centrale Edilizio, specificava come fosse auspicabile, per promuovere l'attività edilizia nelle zone di espansione della Capitale, programmare progetti di borgate giardino, caratterizzate da 'ca-
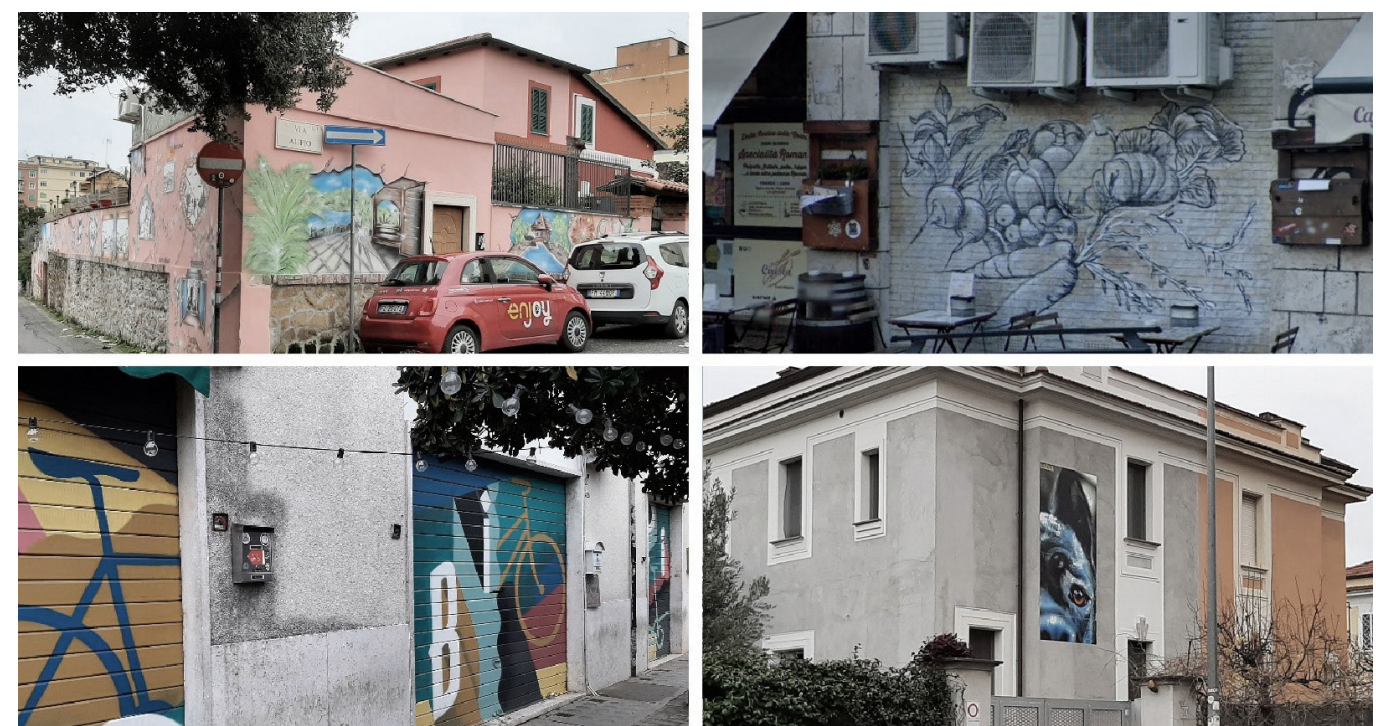

sette economiche' e villini. Precisava, infatti, Giovannoni: "Nel complesso dei provvedimenti escogitati per dare impulso alla ripresa edilizia in Roma, la creazione di borgate-giardino è stata ideata principalmente per tre scopi: per decentrare topograficamente le tendenze fabbricative, analogamente a quanto avviene nelle principali metropoli, varcando la cerchia chiusa della città e portando nuovi centri embrionali in luoghi campestri; per rendere possibile la piccola, ridente e sana abitazione famigliare in condizioni economiche a cui le zone centrali sono inadatte, mentre che le regioni del lontano suburbio il costo diviene mite, sia per il prezzo minimo dell'area (il quale esclusa ogni speculazione parassitaria sul valore 
Fig. 5. Planimetria con gli interventi delle cooperative edilizie attive a Roma tra il 1919-1936 (elaborazione grafica V. Apostoli). potenziale, non può che equivalere al valore agricolo) sia per l'economia nella costruzione, data da facili fondazioni e da materiali murari relativamente poco costosi; per poter realizzare nel tipo di fabbricati bassi e semplicissimi la massima rapidità di esecuzione, elemento essenziale per recare un pronto efficace contributo alla soluzione della gravissima crisi edilizia attuale" [Giovannoni 1919] [6].

Questo modello insediativo, negli anni Venti, diventa il riferimento delle numerose lottizzazioni edilizie promosse dalle cooperative che a Roma, con vari interventi, risponderanno alla pressante richiesta di alloggi sia per la borghesia che per il ceto impiegatizio, medio e basso (fig. 5). I progetti di decentramento residenziale della Capitale, come quello del Pigneto, nati in zone dove era relativamente basso il prezzo del terreno, diventano infatti l'occasione per sviluppare una ricerca sull'abitazione per la classe media e i ceti popolari che recupera la cultura storica locale in alternativa al modello dei sobborghi operai dell'Ottocento.

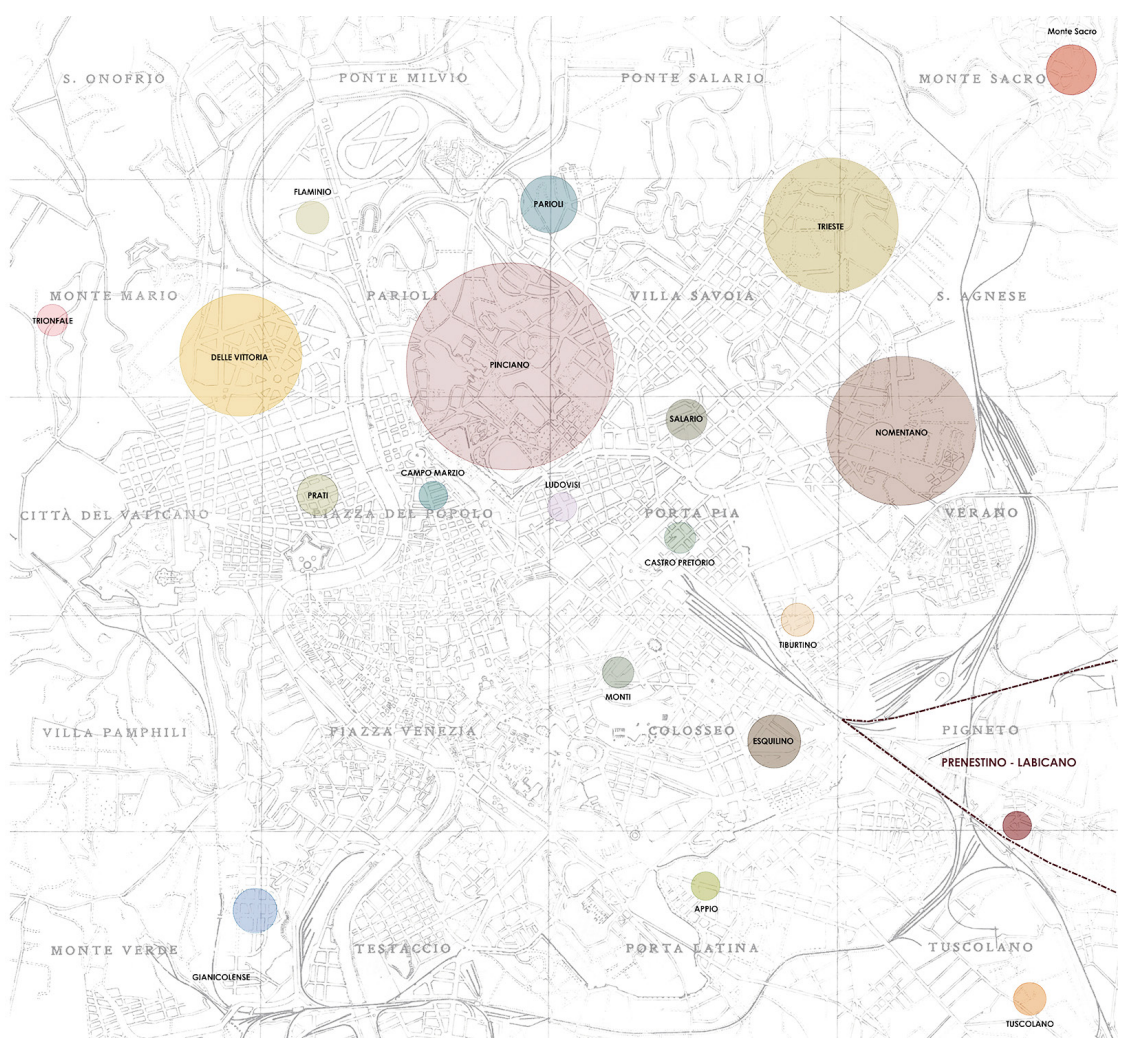

Al Pigneto, la borgata giardino nasce grazie alla fondazione della 'Società Cooperativa Termini fra i ferrovieri di Roma per la costruzione di case economiche', che si costituisce il 31 maggio 1919, come documenta la planimetria del quartiere conservata presso l'Archivio Storico della Cooperativa Termini (fig. 6).

I ventidue soci fondatori chiedono un mutuo all'amministrazione delle Ferrovie dello Stato per l'acquisto di un terreno, destinato a una lottizzazione di villini bifamiliari. L'iniziativa viene programmata al fine di destinare ai soci una: "casa isolata per avere a disposizione tutto il conforto desiderabile per la economia domestica nel coltivare il circostante terreno e allevare degli animali domestici" [7].

Con il mutuo di 7 milioni e mezzo di lire, concesso dalle Ferrovie dello Stato, si procede all'acquisto del terreno, scelto dopo diversi sopralluoghi, nell'area tra la via Casilina e il vicolo del Pigneto, di proprietà della famiglia Serventi. II primo appezzamento di terreno, di mq 45.779, detto Vignola, con accesso dalla via del Pigneto, viene venduto da Giulio Serventi; il secondo, di mq 80.894, con accesso da via Casilina, sarà venduto da Pio Serventi. 
Fig. 6. Piano regolatore Società Cooperativa "Termini" fra i ferrovieri di Roma - Costruzioni di Case economiche. Archivio Storico della Cooperativa Termini.

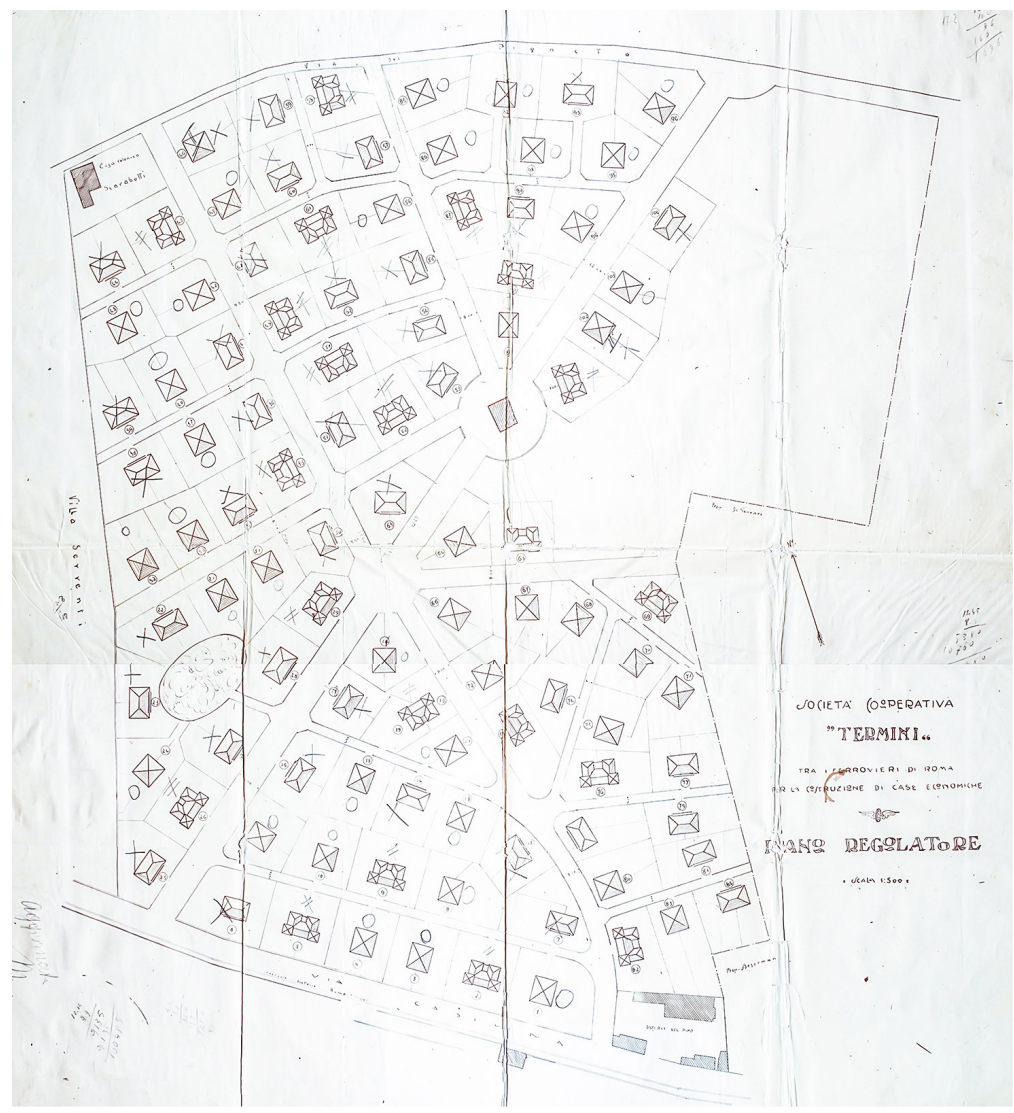

|| 22 aprile 1920, la Cooperativa affida l'incarico del progetto a Gino Rossi, mentre la direzione lavori all'impresa di Romeo Cametti e Vincenzo Marotta. II progetto viene presentato all'Ispettorato Edilizio del Comune di Roma nel settembre 1920, dopo avere ottenuto l'autorizzazione del Ministero dell'Agricoltura, Industria e Lavoro e della Direzione FS.

L'importanza dell'iniziativa viene documentata sulle pagine de II Messaggero (29 novembre 1920) che riportata la cronaca della Posa della prima pietra per le case dei ferrovieri:"leri mattina alle 10 reVittorio Emanuele ha posto la prima pietra delle case dei ferrovieri sulla via Casilina e propriamente nella località detta Vigna Serventi. Le nuove case che verranno costruite dal sig. Marotta su disegno dell'ing. Romeo Cametti saranno un centinaio e consteranno ciascuna di otto o dodici stanze. Esse sorgono per iniziativa della Cooperativa Termini fra i ferrovieri" [Il Messaggero, 29 novembre 1920].
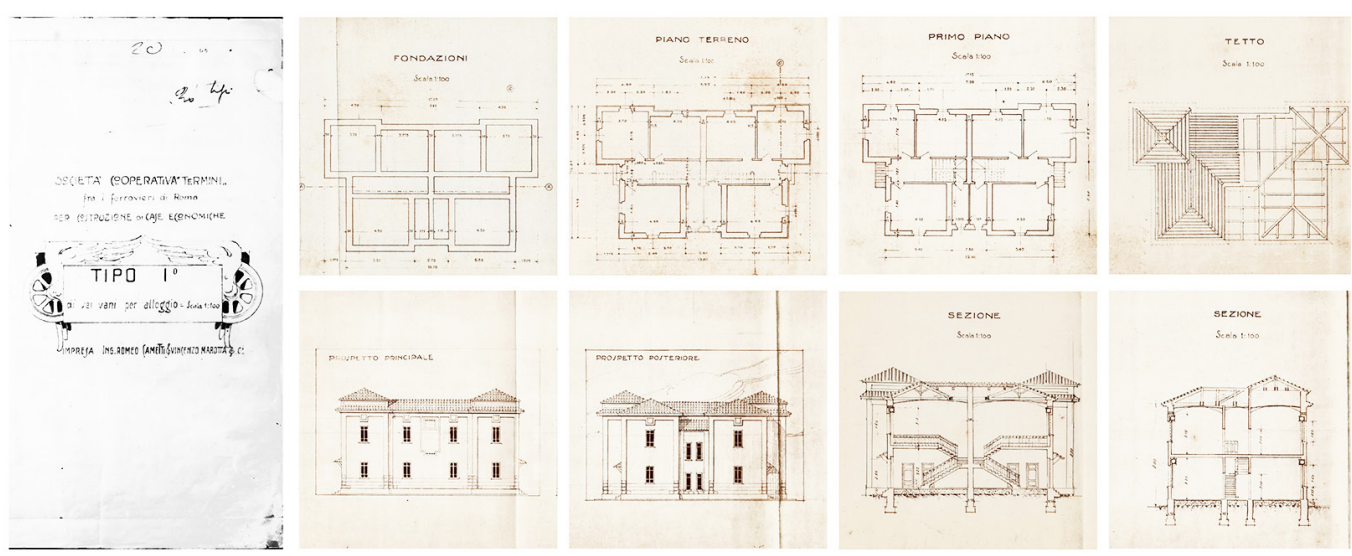

Fig. 7. Progetto del tipo I Società Cooperativa di Roma - Costruzioni Cose economicheioni di Case Ing. Romeo Cametti \& Vincenzo Marotta. Archivio Storico della
Cooperativa Termini.
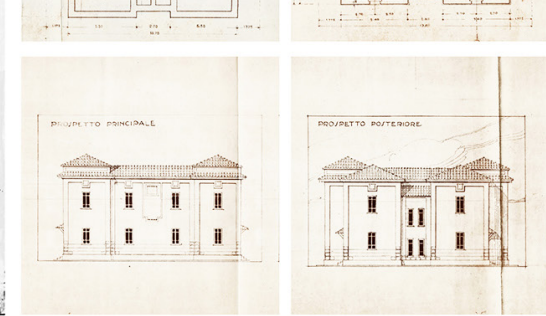

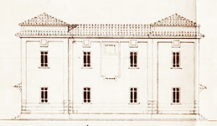

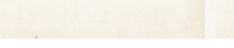

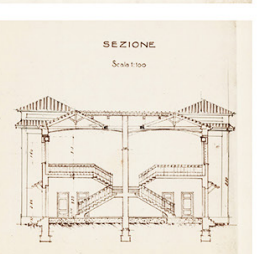

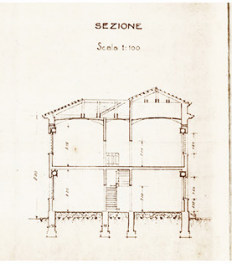


II nuovo quartiere era stato pensato per ospitare 253 residenze, divise in 128 villini, di cinque differenti tipi edilizi, su lotti di 400 mq, e comprendeva anche la sede della Cooperativa e una scuola elementare. Rispetto a questa prima proposta, l'impianto urbano e architettonico varia più volte e il definitivo progetto conterà 109 villini bifamiliari, con tre diversi tipi edilizi (I-III), costruiti nel corso di un decennio e terminati nel 1930 [Severino 2005, pp. 78-8I].
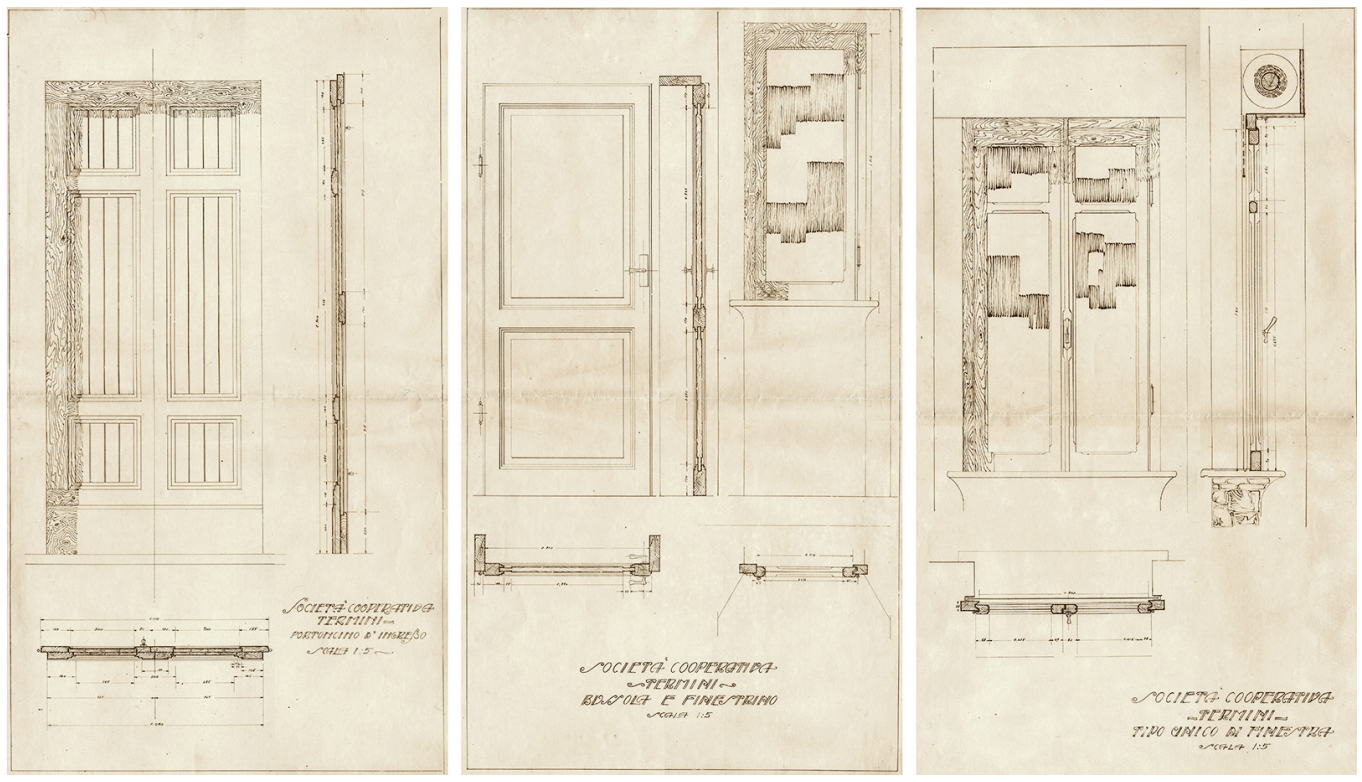

\section{I villini della borgata giardino del Pigneto: studio dei documenti storici e rilievo}

Le caratteristiche urbane, architettoniche e costruttive della borgata giardino sono state ricostruite grazie al ricco patrimonio di documenti inediti (relazioni, disegni, fotografie) conservati all'Archivio Storico della Cooperativa Termini, presso i locali della 'torretta' in Piazza Copernico. La ricerca si è avvalsa, inoltre, di una serie di fonti orali, grazie alla preziosa testimonianza di alcuni residenti storici, che hanno permesso di comprendere le successive trasformazioni degli edifici.

In particolare, rispetto ai tipi edilizi progettati, sono stati individuati i tre tipi portanti, che già in fase di costruzione avevano subito modifiche a livello di dimensione e di finiture (figg. 7, 8). Tramite il rilievo e la verifica con la documentazione fotografica di cantiere, è stato possibile identificare le trasformazioni e classificare gli elementi architettonici ricorrenti in ogni tipo edilizio.

La ricerca è stata approfondita attraverso la consultazione dei documenti conservati all'Archivio Storico Capitolino e all'archivio privato della Famiglia Tavoletti, proprietari di gran parte dei terreni del Pigneto fino alla prima metà del Novecento.

II rilievo dei tre tipi edilizi è stato determinante per la ricostruzione storica e ha permesso di cogliere le peculiarità originarie degli edifici e le attuali alterazioni.

Un primo disegno (l'eidotipo) è stato eseguito sul posto in modo da annotare le misure prese tramite metro e distanziometro laser. La fase seguente si è svolta attraverso la fotogrammetria terrestre e SFM. In sede di restituzione, le misure acquisite tramite raddrizzamento da singolo fotogramma, sono state confrontate con le misure prese tramite il rilievo diretto. Nella fase successiva, la restituzione, dopo aver selezionato le immagini per ottenere un modello accurato, è stata affidata al software Photoscan $V$, secondo le consuete procedure [Kraus 2016], che ha generato un modello 3D fotogrammetrico di ogni villino, da cui si sono ottenute le ortofoto. In tal modo è stato possibile rappresentare in maniera accurata prospetti ed elementi architettonici. 
Attraverso la comparazione tra la ricostruzione filologica e il rilievo dello stato attuale, a livello urbano e architettonico, è stato possibile verificare lo stato di conservazione della borgata giardino. Confrontando gli estratti catastali e la base planimetrica dello stato attuale, sono state individuate le superfetazioni presenti nel 1962, distinguendo quelle da considerarsi come superfetazioni consolidate, da quelle di costituzione più recente (fig. 9). II rilievo sistematico delle superfetazioni dello stato attuale, che risponde alle definizioni date dalla normativa della Provincia di Roma, ha permesso di classificare i diversi processi di trasformazione della borgata giardino (fig. I0). La stessa modalità è stata adottata nell'affrontare la scala architettonica e di dettaglio, scegliendo tre casi studio, uno per ogni tipo edilizio, esemplificativi dei vari livelli di trasformazione (fig. I I). Un abaco di dettaglio degli elementi di finitura, dei rivestimenti e delle cancellate è stato realizzato per evidenziare quei particolari che costituiscono parte integrante del lessico formale architettonico della borgata giardino del Pigneto (fig. 12).

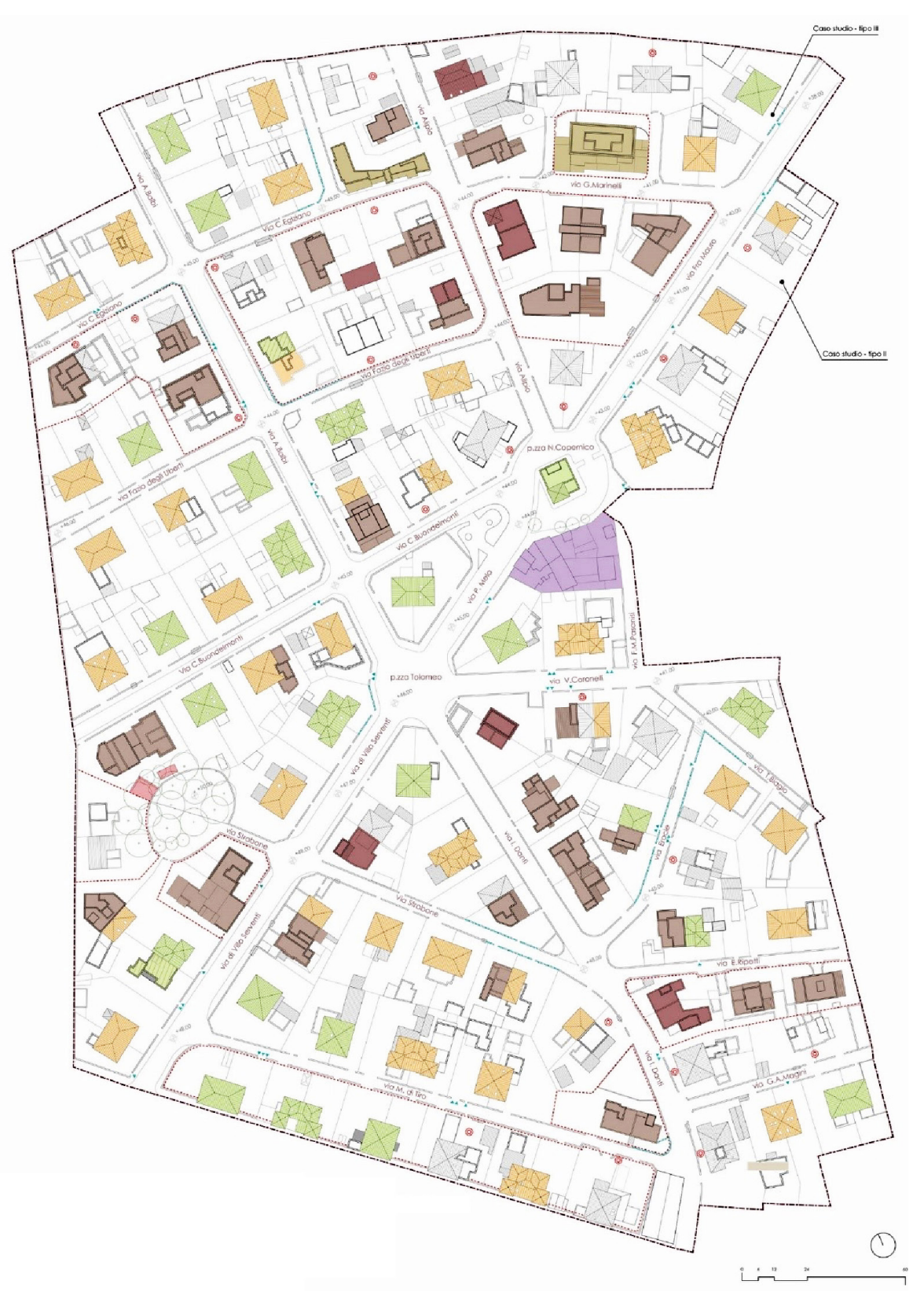


Fig. I0. Fotomosaico delle principali trasformazio

edilizie del villini della

borgata giardino del

Pigneto (elaborazione
grafica Valentina Apostoli).
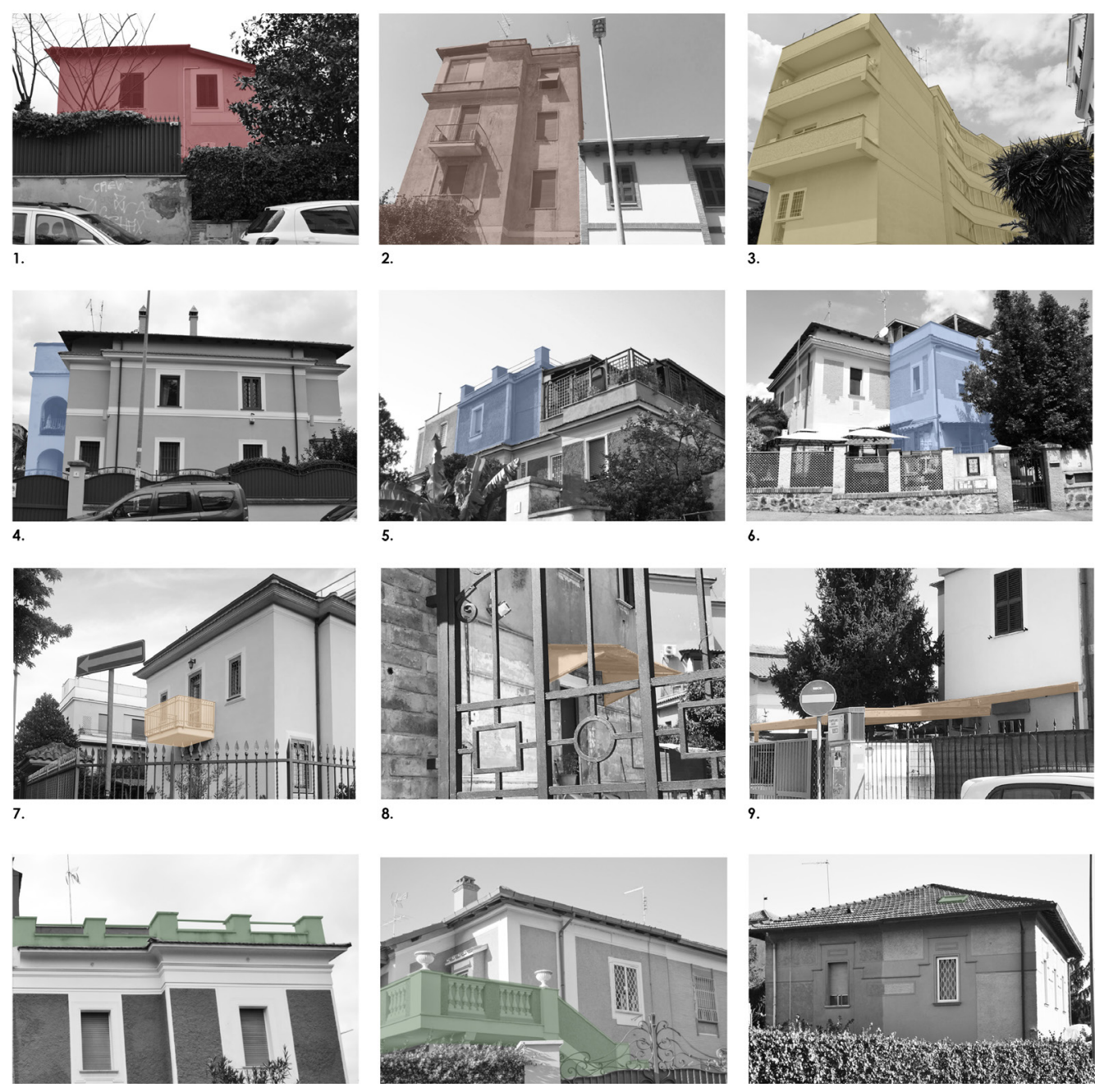

Fig. I I. Rilievo dello stato di degrado di uno dei vil-

lini della borgata giardino del Pigneto (elaborazione grafica Valentina Apostoli).

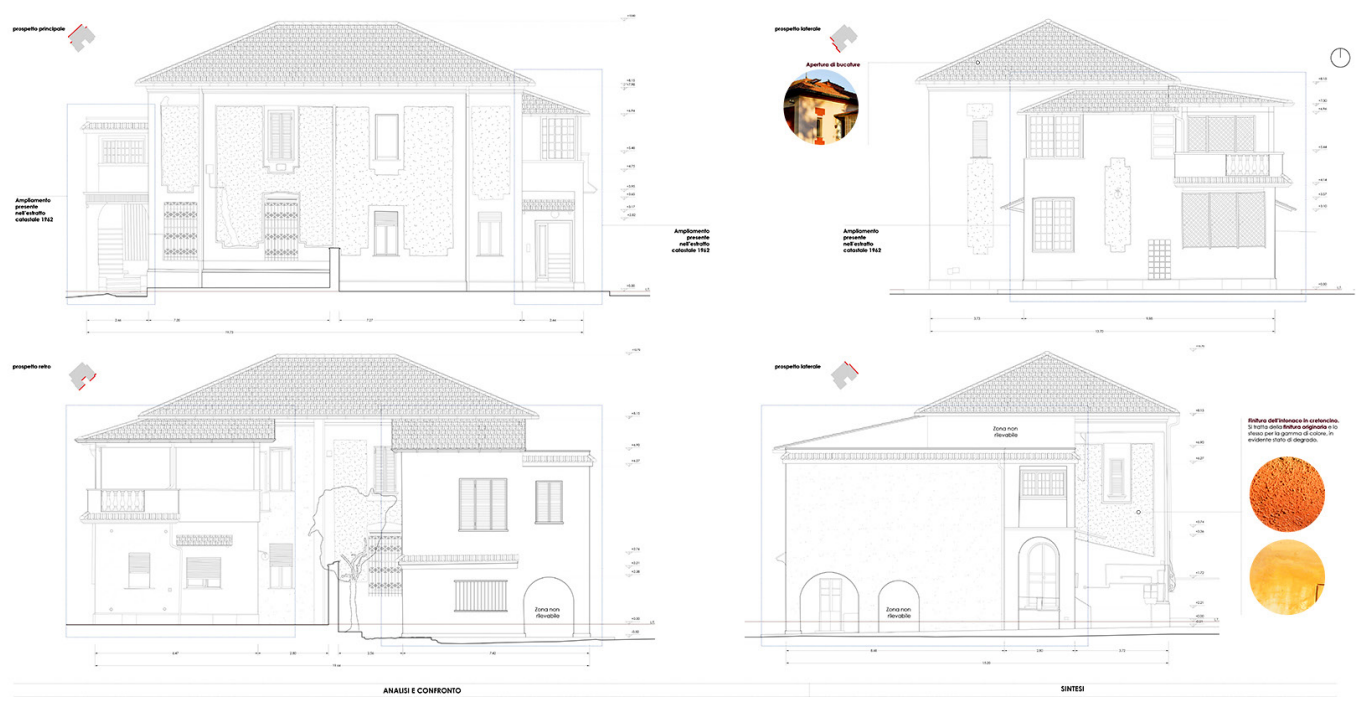




\section{Conclusioni}

Attraverso questo studio è stato possibile rilevare i caratteri insediativi, tipologici e architettonici del Pigneto e ricostruire una storia urbana ed edilizia rappresentativa della Roma del Novecento. Infatti, i nuclei di villini costruiti al Pigneto, così come a Monteverde, a Garbatella o a Montesacro, costituiscono per la città un importante patrimonio architettonico da tutelare. In tal senso, il confronto tra passato e presente, ha l'obbiettivo di gettare le basi per un possibile progetto di recupero della borgata giardino, che parta da un percorso metodologico di rilievo e di ricostruzione storica del quartiere e che consenta di connettere attraverso il presente la memoria storica degli anni Venti della borgata giardino, insieme a quella degli anni Sessanta, raccontata da Pasolini. Due fasi storiche apparentemente distanti, riunite attraverso una lettura trasversale che consente di rileggerne affinità e similitudini. In questi ultimi anni, come accennato, l'interazione con il centro storico della città, la vitalità che caratterizza il Pigneto e le contaminazioni artistiche che contraddistinguono l'immagine del quartiere, attirano sempre più persone e la borgata giardino, seppure ancora riconoscibile, rischia di perdere molte delle sue peculiarità che andrebbero invece salvaguardate e valorizzate.
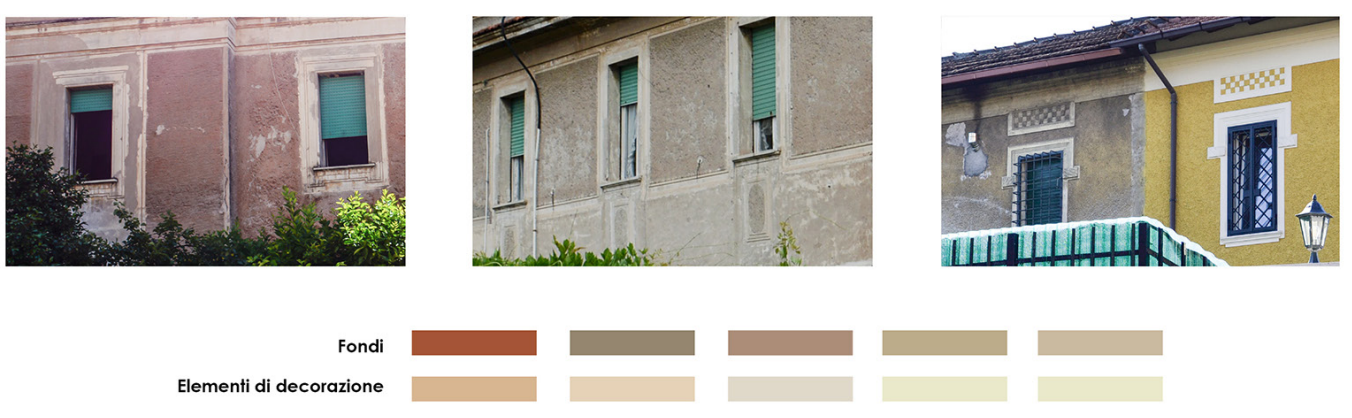

Finitura intonaco
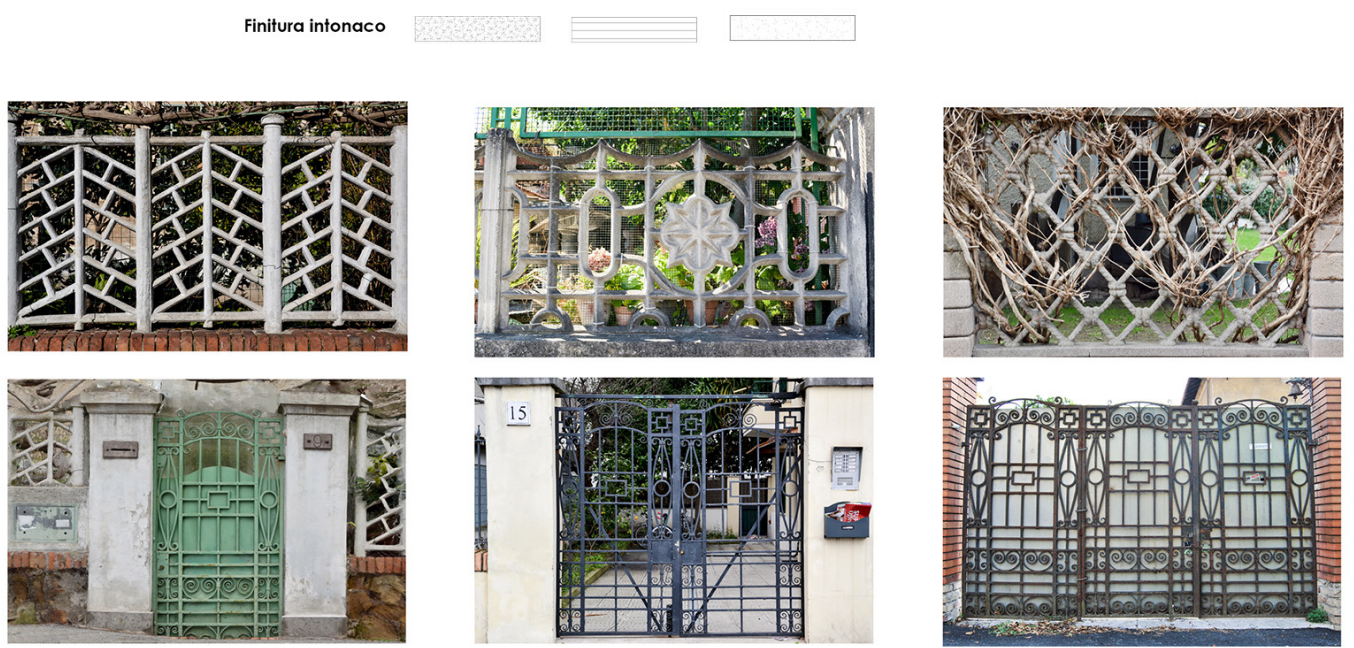

menti e delle cancellate di alcuni villini della borgata giardino del Pigneto (elaborazione Valentina Apostoli).

\section{Note}

[I] Dai frame del video di acquisizione del modello di GoogleEarth è stato possibile ottenere un modello 3D dell'area in esame, utilizzando la metodologia di restituzione fotogrammetrica SFM (Structure from Motion) e il programma Metashape [Canciani, Fioravanti 2019; Chen, Clarke 2016].

[2] Accattone, film scritto e diretto da Pier Paolo Pasolini (196I), con Sandro Citti, Franca Pasut, Silvana Corsini, Paola Guidi, Adriana Asti.

[3] Magliaro A. (20I4). Uno scrittore e un luogo: Pasolini e il Pigneto dal sito ansa.it <https://www.ansa.it/lifestyle/notizie/people/ storie/20 I 4/07/3 I/uno-scrittore-e-un-luogo-pierpaolo-pasolini-e-il-pigneto> (consultato il 20 gennaio 202 I). 
[4] La variante del PRG del 1977 vede passare il Pigneto da zona C - Ridimensionamento viario e edilizio (di sostanziale espansione), alla zona B di conservazione del tessuto edilizio [cfr. Severino 2005, p. I99].

[5] La 'gentrificazione' è quel fenomeno di rigenerazione urbana di alcuni quartieri periferici che porta all'aumento esponenziale dei prezzi delle abitazioni con conseguente migrazione degli abitanti originari verso altre aree urbane, più economiche.

[6] Giovannoni G., Relazione della Commissione Tecnica del 1919 del Comitato Centrale Edilizio per la costruzione di case popolari in Roma, Centro di Studi per la Storia dell'Architettura, Roma, Fondo Giovannoni.

[7] Archivio Storico Cooperativa Termini, Roma, Libro dei Verbali del Consiglio, seduta del 7 agosto 1920, p. 84.

\section{Riferimenti bibliografici}

Apostoli V. (2019). La Cooperativa Termini al Pigneto 1919-1930. Storia, rilievo e conservazione. Tesi di laurea Magistrale in Architettura-Restauro. Relatori M. Canciani, F.R. Stabile. Dipartimento di Architettura, Università degli Studi Roma Tre.

Bartolini F. (200 I). Roma borghese: la casa e i ceti medi tra le due guerre. Roma-Bari: Laterza.

Benevolo L. (1992). Roma dal 1870 al 1990. Roma-Bari: Laterza.

Boldi M.A. (1910). Le Case Popolari. Milano: Hoepli.

Brunori G., Cretarola A., Zampilli M. (20 I 6). Tivoli: lettura di una città. In U+D urbanform and design, n. 05/06, pp. 32-49.

C. G. ( 1 925). Edilizia in Roma. In Capitolium, I, n. I, pp. 44-49.

Canciani M., Sturm S., G. Fioravanti (2020). Il cielo sopra Foligno. Rilievo 3D del centro storico tramite tecnologia aeromobile a pilotaggio remoto (APR). In Sturm S. (a cura di). Foligno. I palazzi e la città dal Rinascimento al Neoclassico. Perugia: Quattroemme.

Canciani M., et al. (2019). Cartografia aggiornata del centro storico di Tivoli: contributi al GIS del territorio del Comune. In Martines R., Pallottino E. (a cura di). Tivoli, un laboratorio urbano. leri, oggi, domani. Roma: Edizioni Roma TrE-Press, pp. $97-126$.

Casali I. (1909). Tipi originali di casette popolari e villini economici. Milano: Hoepli.

Chen J., Clarke K. (20I6). Rapid 3D Modeling Using Photogrammetry Applied to Google Earth. In Proceedings, Autocarto 2016 . The 2 Ist International Research Symposium on Computer-Based Cartography and GIScience. Albuquerque, New Mexico, pp. $\mid 4-27$

Giovannoni G. (1919). Relazione della Commissione Tecnica del 1919 del Comitato Centrale Edilizio per la costruzione di case popolari in Roma. Centro di Studi per la Storia dell'Architettura, Roma, Fondo Giovannoni.

Kraus K., (2007). Photogrammetry: Geometry from Images and Laser Scans. Berlino: De Gruyter Textbook.

Magliaro A. (20|4). Uno scrittore e un luogo: Pasolini e il Pigneto <https://www.ansa.it/lifestyle/notizie/people/storie/20 I 4/07/3I/ uno-scrittore-e-un-luogo-pierpaolo-pasolini-e-il-pigneto> (consultato il 20 gennaio 202I).

Pasolini P.P. (1955). Ragazzi di vita. Milano: Garzanti.

Remondino F., El-Hakim S. (2006). Image-based 3D modelling: a review. In The Photogrammetric Record, vol. 2 I ( I I 5), pp. 269-29 I .

Schiavi A. (|9||). Le case a buon mercato e le città giardino. Bologna: Zanichelli.

Severino C.G. (2005). Roma mosaico urbano: il Pigneto fuori Porta Maggiore. Roma: Gangemi.

Stabile F.R. (2019). La Garbatella a Roma. Architettura e regionalismo. Roma: Quasar

Autori

Marco Canciani, Università degli Studi RomaTre, marco.canciani@uniroma3.it

Francesca Romana Stabile, Università degli Studi RomaTre, francescaromana.stabile@uniroma3.it

Valentina Apostoli, Università degli Studi RomaTre, apostolivalentina@gmail.com

Per citare questo capitolo: Canciani Marco, Stabile Francesca Romana, Apostoli Valentina (2021). Linguaggi architettonici tra presente e passato: la borgata giardino del Pigneto/Architectural languages between past and present: the city garden of Pigneto. In Arena A., Arena M., Mediati D., Raffa P. (a cura di). Connettere. Un disegno per annodare e tessere. Linguaggi Distanze Tecnologie. Atti del $42^{\circ}$ Convegno Internazionale dei Docenti delle Discipline della Rappresentazione/Connecting. Drawing for weaving relationship. Languages Distances Technologies. Proceedings of the $42^{\text {th }}$ International Conference of Representation Disciplines Teachers. Milano: FrancoAngeli, pp. 307-328 


\title{
Architectural Languages between Past and Present: the Garden City of Pigneto
}

\author{
Marco Canciani \\ Francesca Romana Stabile \\ Valentina Apostoli
}

Abstract

The COVID-19 pandemic has had devastating effects on many fields - political, social and cultural. However, in scientific research, it gave a stimulus to find a renewed interest in the development of analytical and interdisciplinary languages, in bridging both physical and intellectual gaps thanks to telecommunication, in optimizing multimedia and digital technologies. The aim of this paper is to provide a wide spectrum of viewpoints on the urban structure of the borgata Pigneto, a city garden at east of Rome, thanks to a cross-disciplinary research that faces the need of scientific interaction due to the present conditions. The suburb in its present state has been analysed in relation to the design hypothesis of 1920-1921 and to the density of the Sixties, when the history of Pigneto ties to the film Accattone by Pier Paolo Pasolini. In some scenes of the film, the villini, the typical houses of the borgata, are the background to the shooting, showing suggestive and evocative images. Today, there are several evidences of garden cities that reveal a defined and clear architectural language, often with incongruous expanded and transformed areas.

Keywords

Rome, Pigneto, suburban garden, architectural language, urban and architectural survey.

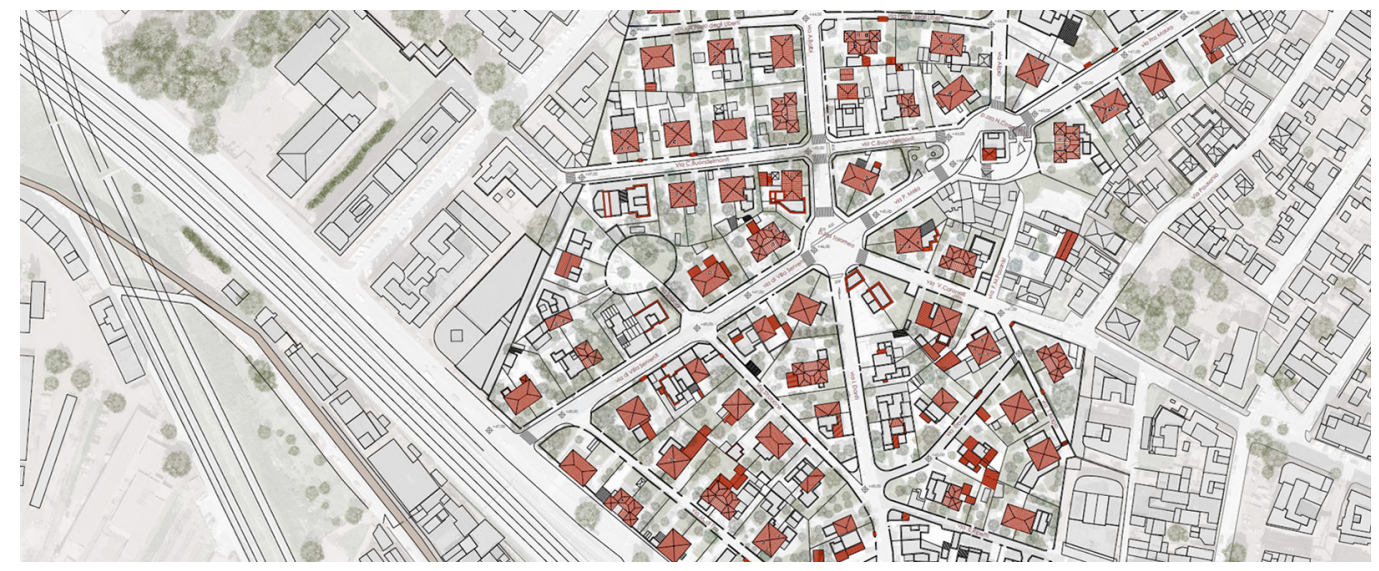




\section{Introduction}

The state of segregation and isolation, created by the pandemic due to COVID-19 -whose effects over the last year have been devastating from many points of view and in all sectors, political, social, and cultural- has generated in the scientific community a deep sense of stasis and detachment from the applied fields, on the one hand, and, on the other, a renewed interest in the development of digital and multimedia technologies and new analytical languages, capable of integrating multidisciplinary skills and reducing not only physical separation, via digital conferencing, but also intellectual. The study, of which this is a first summary, concerns the analysis of an urban environment, the garden borough in the Pigneto district, with the aim of understanding its typological, architectural, and settlement characteristics, through a multilevel reading [Brunori, Cretarola, Gushes 2016, p. 42.] This research, with a bachelor's degree thesis [Apostoli 2019-2020] as its first outcome, is part of several years of ongoing work oriented towards the analyses of minor urban contexts and the historical Roman periphery [Canciani et al. 2019; Stable 2019], which involves contributions and interactions of different disciplines, Drawing and Survey, History, and Restoration, so as to obtain a multiform and multilevel reading, beginning with the study on an urban scale, up to that of the individual building. The methodology involved the first phase of acquisition of the survey data of the urban structure, carried out 'at a distance', using a 3D model derived from the images acquired from the Google Earth application [I] (fig. I), with which it was possible to compare a reference planimetry of the current state and the various historical plans (such as, for example, the areas hammered by the 1943-44 bombings), to understand the transformations that occurred over time (fig. 2).

Fig. I. Axonometric view from model obtained by Google Earth images of the garden borough. The homogeneity of the villin in the urban structure and the main roads that intersect in Tolomeo square are highlighted graphic elaboration by G. Fioravanti and $M$. Canciani).

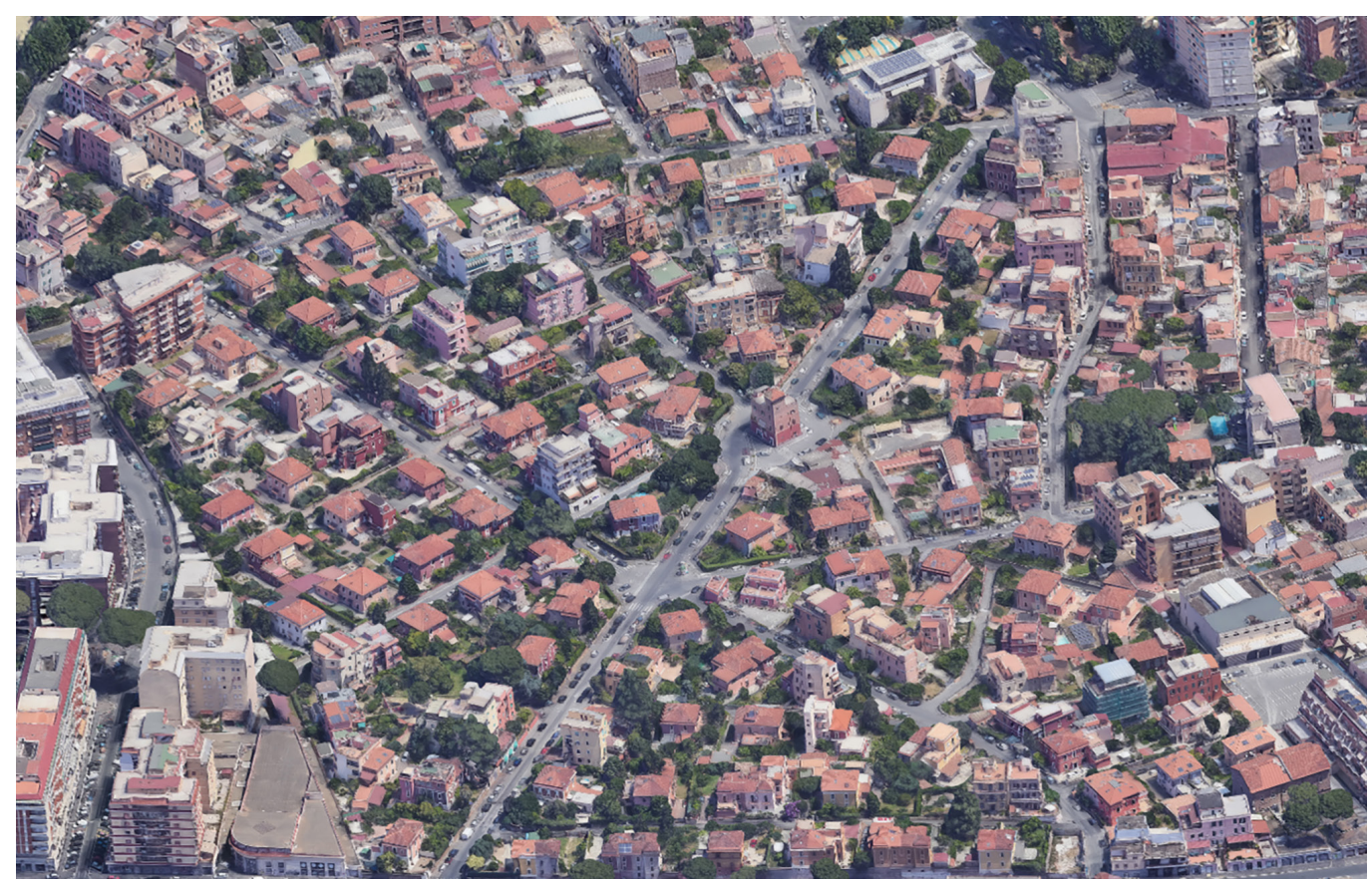

\section{Pigneto from the 60 s to now}

Heavily damaged by the 1943 and 1934 bombings, the Pigneto, described by Pier Paolo Pasolini in his film Accattone [2], in the early 1960s, belonged to "a Rome that was not Rome, evolved as a succession of scaffolding and buildings under construction, and large fields, scrap yards, building plots" [Pasolini 1955, p. 85]. With the massive immigration from Central and Southern Italy, Pigneto represented "the home of the lower class, the poor day laborers, while, two streets away, railwaymen and workers had respectable houses" [Magliaro 2014] [3]. In the 
Fig. 2. Planivolumetric view of the garden the villas and trees in evidence, superimposed on the rectified orthophoto (graphic elaboration by V.Apostoli).

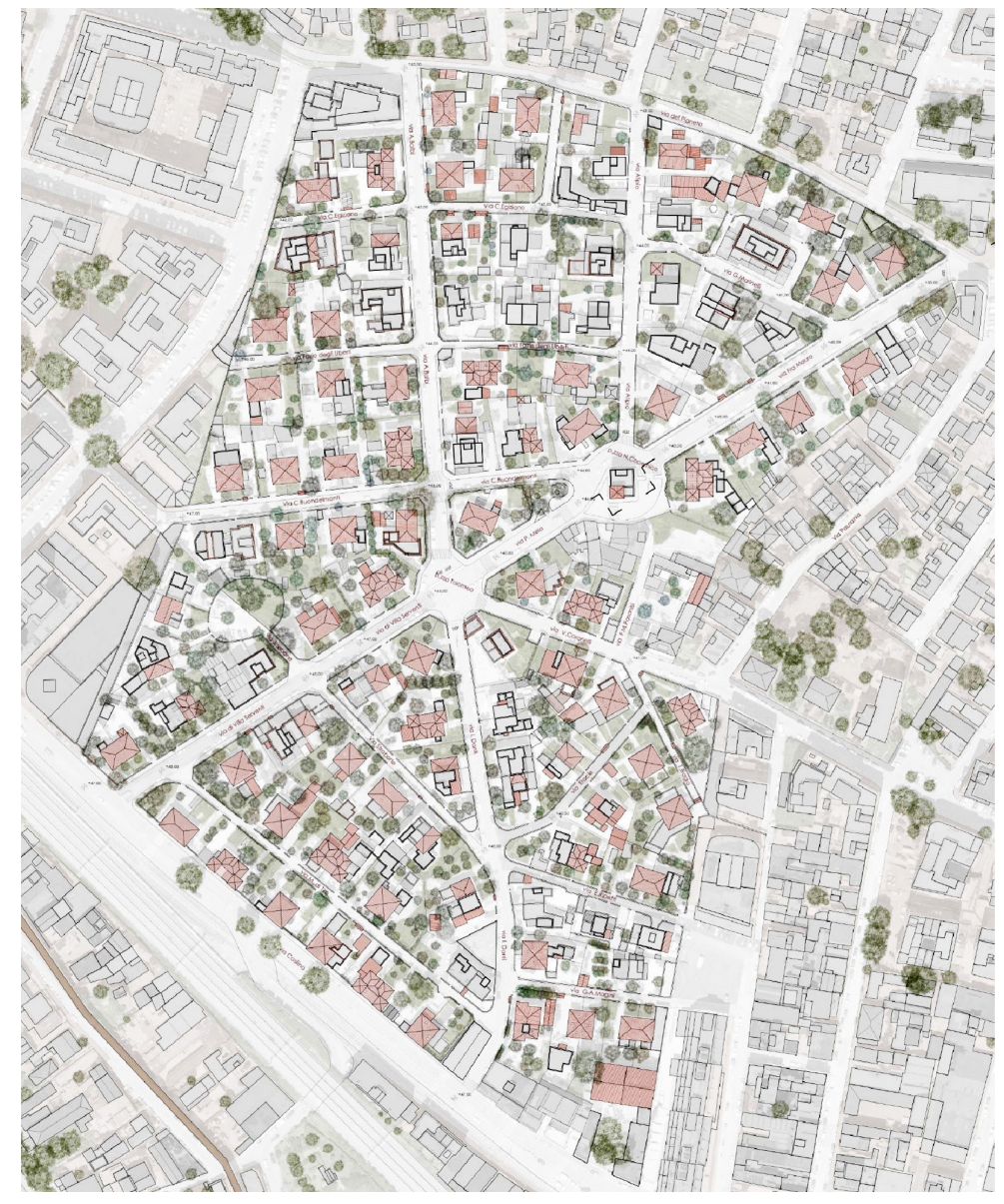

still from the film (fig. 3), the striking contrast is evident between the shacks of the borough and the villini (detached homes) of the Railworkers' Termini Cooperative, which represented an autonomous enclave, enclosed in a separate area, between via del Pigneto, via Casilina, via De Agostini and via Pausania.

Between the sixties and nineties, the entire area east of Rome, stimulated by the 1962 PRG, urban development plan, saw a considerable expansion, with the construction of the eastern ring, in support of the planned Sistema Direzionale Orientale (eastern management system), and several intensive construction nuclei. Even areas in Pigneto's perimeter were affected by a process of reconstruction and replacement with buildings but, with the 1967 PRG variant, the area of the garden borough of the Termini Cooperative was spared the building speculation, classified as area B for the conservation of urban structure [4] (only some intensive buildings were built in the area). The redevelopment program of 1988 went in the same direction, which also directly affected the Termini Cooperative.

From 2000 until today, Pigneto has in fact been marked by a process of profound transformation and redevelopment of the urban, social, and building network, thanks to the initiatives of the city and municipal administration (such as the construction of the Metro station and the institution of the pedestrian area on via del Pigneto in 20 I5), becoming a more liveable district and an important artistic, cultural, and recreational center of the city, characterized by street art and the lively Roman nightlife. At the same time, the phenomenon of gentrification [5] has led the houses to be divested of their old owners, thus losing its character of popular authenticity, exalted by Pasolini in his works. The Pigneto garden borough seems once more to be extraneous to this phenomenon, even though the echo of the artistic and cultural manifestations reach within it: on the walls and the shutters some murals stand out, animating and contaminating the landscape of the villini of the 1920s (fig. 4). 
Fig. 3. Still taken from the film Accattone, by Pier Paolo Pasolini (1961), in which one can see a ground, a villino beloning ground, a vilno belonging

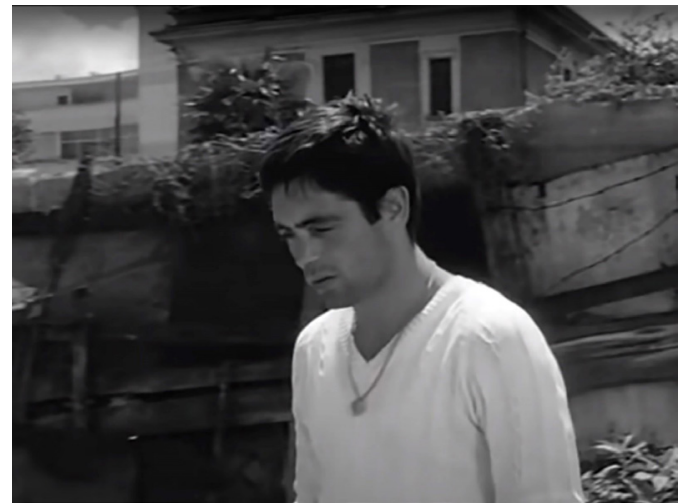

The Pigneto garden borough: historical context and Termini Cooperative, 1919-1930

The project for the Pigneto garden borough was part of the national policy to support building activity after the First World War. With the Royal decree n. 2318, November 30, 1919, the Consolidated law for public and economic housing and the construction industry, ensured a set of norms and financial incentives for the Capital.

The law also permitted private cooperatives to obtain mortgages up to the total cost of the land and the building, in compliance with the conditions and criteria set by the Central Building Committee, established by art. 58 of the Consolidated Law.

In November 1919 a report drafted by Gustavo Giovannoni, for the Central Building Committee, specified how it was desirable to promote building activity in the expansion areas of the capital, to plan projects for garden boroughs, characterized by 'affordable housing' and
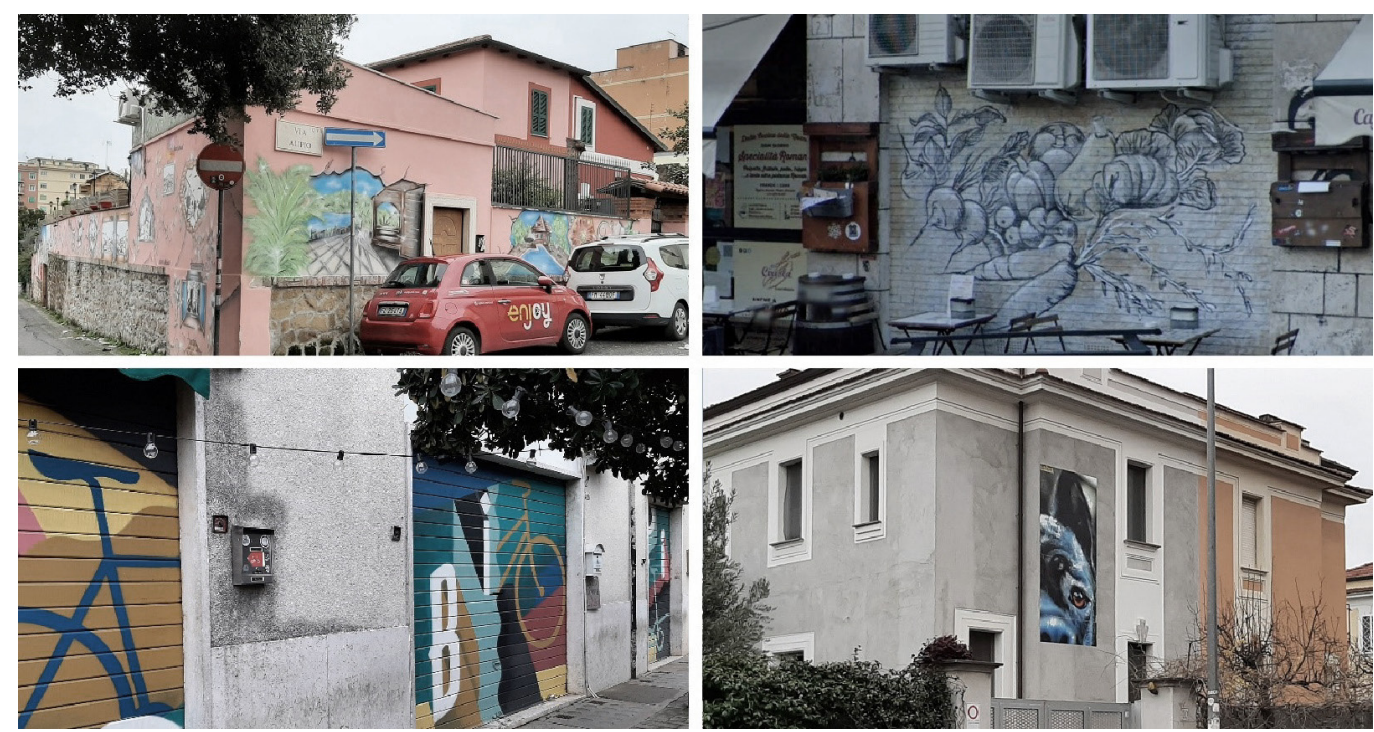

Fig. 4. Some murals in the garden borough and surroundings: a) via Alipio; b) via Pausania; c) and d) by V. Apostoli). villini. In fact, Giovannoni specified that: "In the set of measures devised to give impetus to the construction revival in Rome, the creation of garden boroughs was conceived for three main purposes: to topographically decentralize manufacturing tendencies, similarly to what happens in the main metropolises, by crossing the closed circle of the city and bringing new embryonic centers to rural areas; to make small, charming, and wholesome family homes possible in affordable conditions for which the central areas are unsuitable, when in the regions of the distant suburbs the costs become moderate, both for the minimal price of the area (which, excluding parasitic speculation on the potential value, can only be equivalent to 
the agricultural value) and for the economy of construction, assured with simple foundations and relatively inexpensive masonry materials; to achieve the maximum speed of construction of low and very simple buildings, an essential element to achieve a prompt effective contribution in solving of the very serious current building crisis" [Giovannoni 1919] [6].

This settlement model, in the 1920s, became the reference of the widespread building parceling promoted by the cooperatives which in Rome, with various interventions, will answer the pressing demand for housing for both the bourgeoisie and the middle and lower white-collar class (fig. 5). The capital's residential decentralization projects, such as Pigneto, born in areas where the price of the land was relatively low, in fact became an opportunity to develop research on housing for the middle and the working class that recovers the local historical culture as an alternative to the nineteenth-century model of the workers' suburbs.

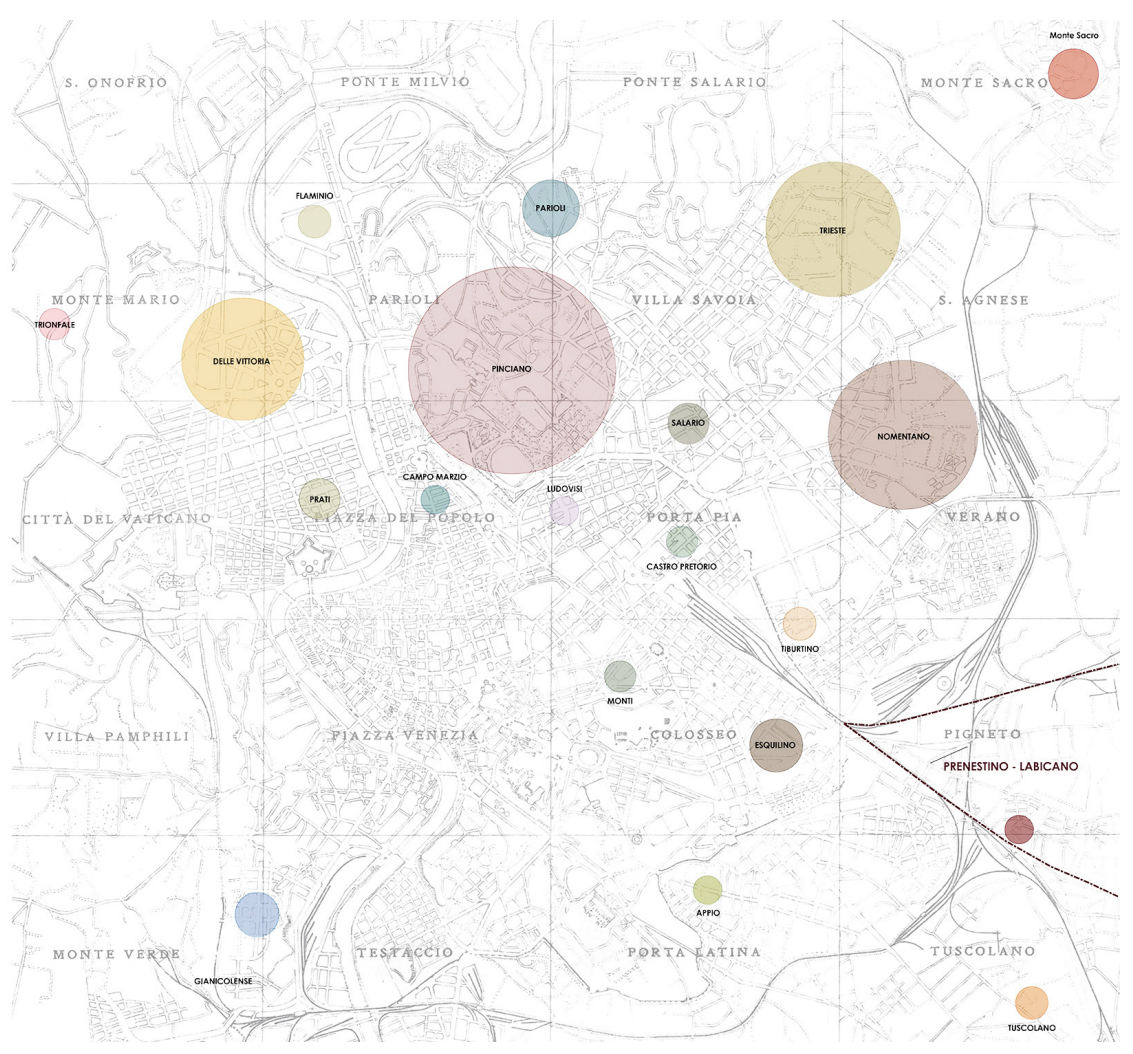

In Pigneto, the garden borough was born thanks to the foundation of the Termini Cooperative Society of railway workers of Rome for the construction of economic housing, established May 31, 1919, as documented in the plan of the district preserved in the Historical Archive of the Termini Cooperative (fig. 6).

The twenty-two founding members apply for a mortgage from the State Railways administration for the purchase of land, intended for a parceling of semi-detached villini. The initiative intends to provide members with an "isolated house providing all the desirable comfort for the household in cultivating the surrounding land and raising pets" [7].

With the loan of 7 and a half million lire, granted by the State Railways, the land was purchased, chosen after various inspections, in the area between via Casilina and vicolo del Pigneto, owned by the Serventi family. The first plot of land, of 45.779 square meters, called Vignola, with access from via del Pigneto, was sold by Giulio Serventi; the second, of 80,894 square meters, with access from via Casilina, would be sold by Pio Serventi. 
Fig. 6. Urban plan, Societá Cooperativa Termini fra I ferrovieri Roma - Construction of affordable housing. Archivio Storico del Cooperativa Termini.
Fig. 7. Type I project, Termini Cooperative Society among the
railway workers of Rome - Construction of affordable housing in Romoo Cametti Vinomeo Camet Q Vincenzo Marotta Archive of istorical Termin Cooperative.

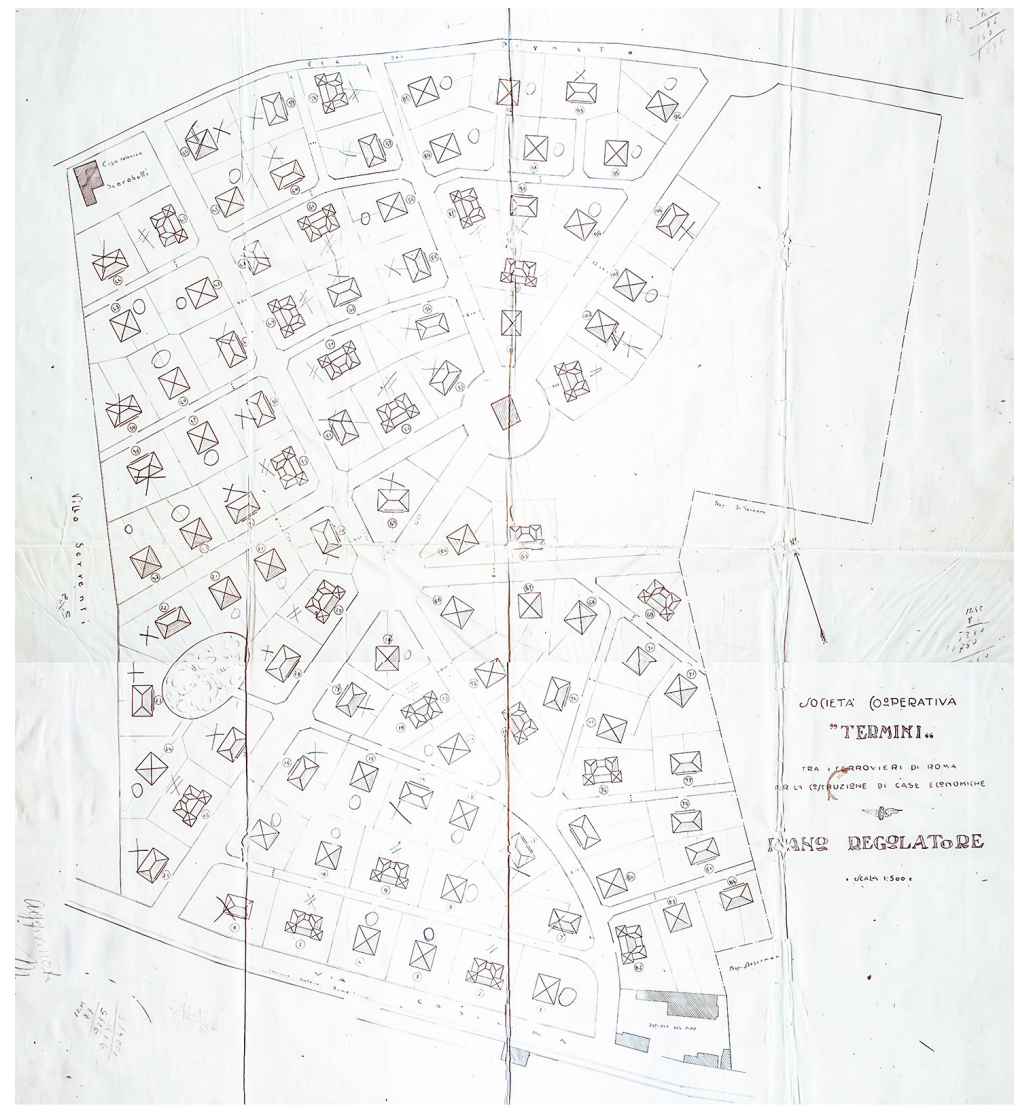

On April 22, 1920, the Cooperative entrusted the project to Gino Rossi, while the construction management to the company of Romeo Cametti and Vincenzo Marotta. The project was presented to the Building Inspectorate of the Municipality of Rome in September 1920, after obtaining the authorization of the Ministry of Agriculture, Industry and Labor and the management of the Italian State Railways.

The importance of the initiative is documented in the pages of II Messaggero (November $29,1920)$ reporting the news of the laying of the first stone for the railway workers' houses: "Yesterday morning at 10, King Vittorio Emanuele laid the first stone of the railway workers' houses on via Casilina and precisely in the locality called Vigna Serventi. The new houses that will be built by Mr. Marotta and designed by Eng. Romeo Cametti will be about one hundred, each consisting of eight or twelve rooms. They come to fruition on the initiative of the Termini Cooperative among railway workers" [II Messaggero, November 29, 1920].

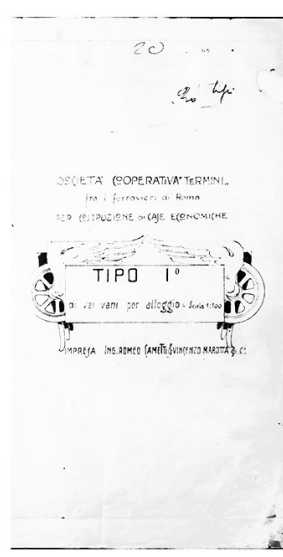

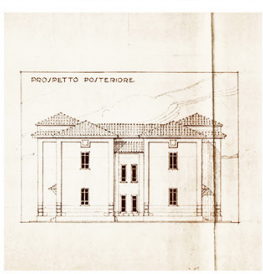

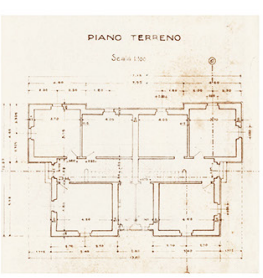

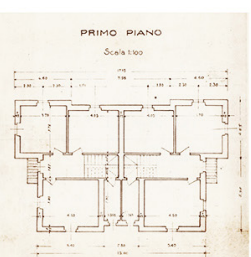
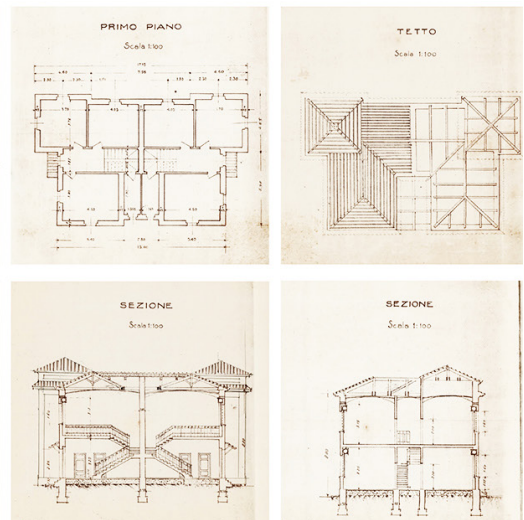

sezione

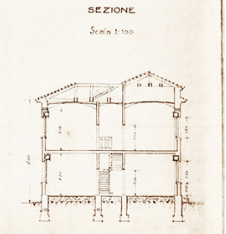


The new district was designed to house 253 residences, divided into 128 villini, of five different building types, on lots of 400 square meters, and also included the headquarters of the Cooperative and an elementary school. Compared to this first proposal, the urban and architectural layout varied several times and the final project will number 109 semi-detached houses, with three different building types (I-III), built over a decade and finished in 1930 [Severino 2005, pp. 78-8I].
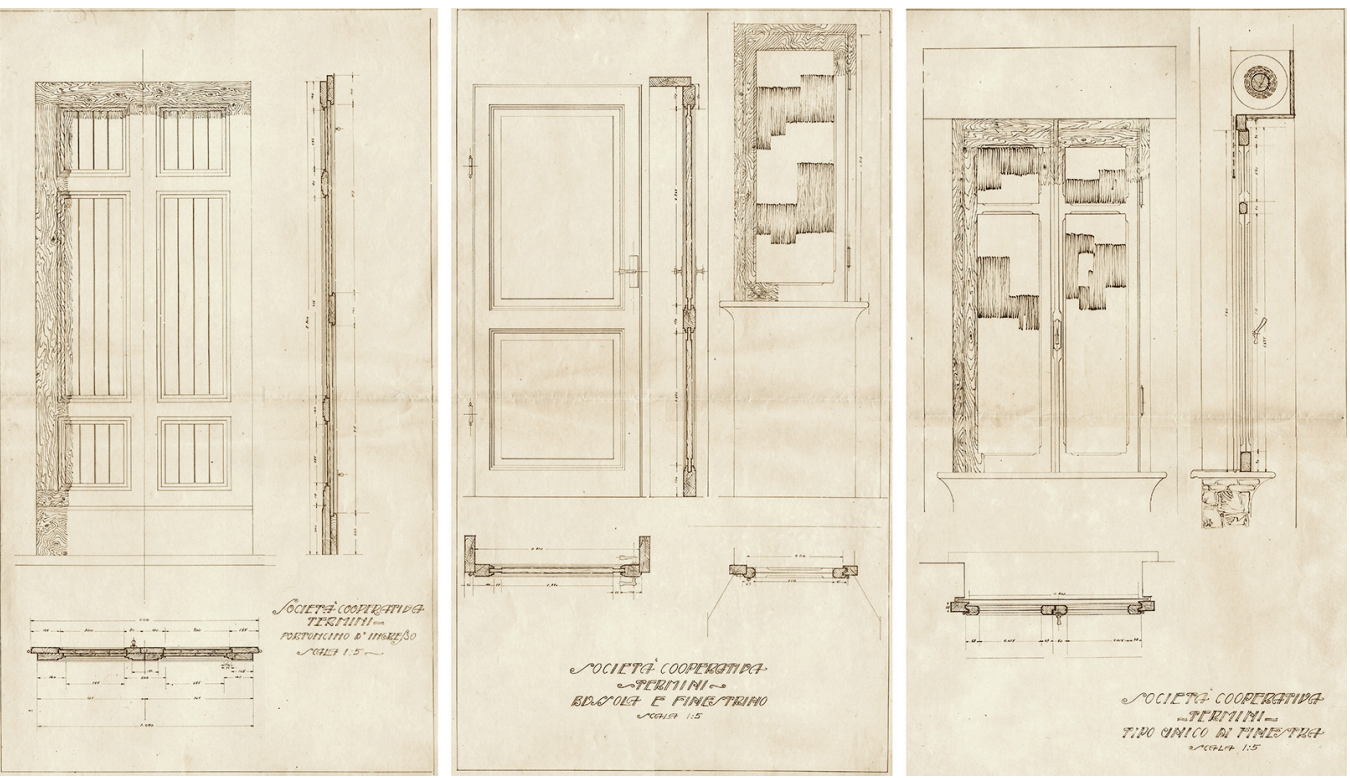

\section{The villini of the Pigneto garden borough: from historical documents and survey}

The urban, architectural, and construction features of the garden borough were reconstructed thanks to the rich heritage of unpublished documents (reports, drawings, photographs) preserved in the Historical Archive of the Termini Cooperative, in the premises of the "torretta" in Piazza Copernico. The research also utilized a series of oral sources, thanks to the precious testimony of some historical residents, which made understanding the subsequent transformations of the buildings possible.

In particular, with respect to the planned building types, the three main types were identified, which already during the construction phase had undergone modifications in terms of size and finishes (figs. 7, 8). Through the survey and verification with photographs of the construction site, it was possible to identify the changes and classify the recurring architectural elements in each building type.

The research was expanded through consultation of the documents stored in the Archivio Storico Capitolino (Capitoline Historical Archives) and in the private archives of the Tavoletti family, owners of much of the land in Pigneto until the first half of the twentieth century. The survey of the three building types was decisive for their historical reconstruction, allowing us to comprehend the original particulars of the buildings and the current alterations. A first on-site drawing (the eidotype) recorded the measurements taken with meter tape and laser distance meter. The subsequent phase took place via terrestrial photogrammetry and SFM. During the restitution, the measurements acquired through single-frame rectification were compared with the measurements taken through the direct survey. In the next phase, the results, after selecting the images to obtain an accurate model, were elaborated by Photoscan $\vee$ software, following the usual procedures [Kraus 2016], which generated a photogrammetric 3D model of each villino, from which orthophotos were obtained. Thus, it was possible to accurately represent elevations and architectural elements. 
Comparing the philological reconstruction with the survey of the current state, on an urban and architectural level, it was possible to verify the state of conservation of the garden borough. By comparing the cadastral extracts and the planimetric base of the current state, the superfetations present in 1962 were identified, distinguishing those to be considered as consolidated superfetations, from those established more recently (fig. 9). The systematic survey of the modifications of the current state, which comply with the definitions contained in the legislation of the Province of Rome, has made it possible to classify the different transformation processes of the garden borough (fig. I0). The same method was adopted when dealing with the architectural and detail scale, selecting three case studies, one for each building type, exemplifying the various degree of modification (fig. II). A detailed list of the finishing elements, the coverings, and gates was created to highlight those details that form an integral part of the formal architectural lexicon of the Giardino del Pigneto borough (fig. 12).

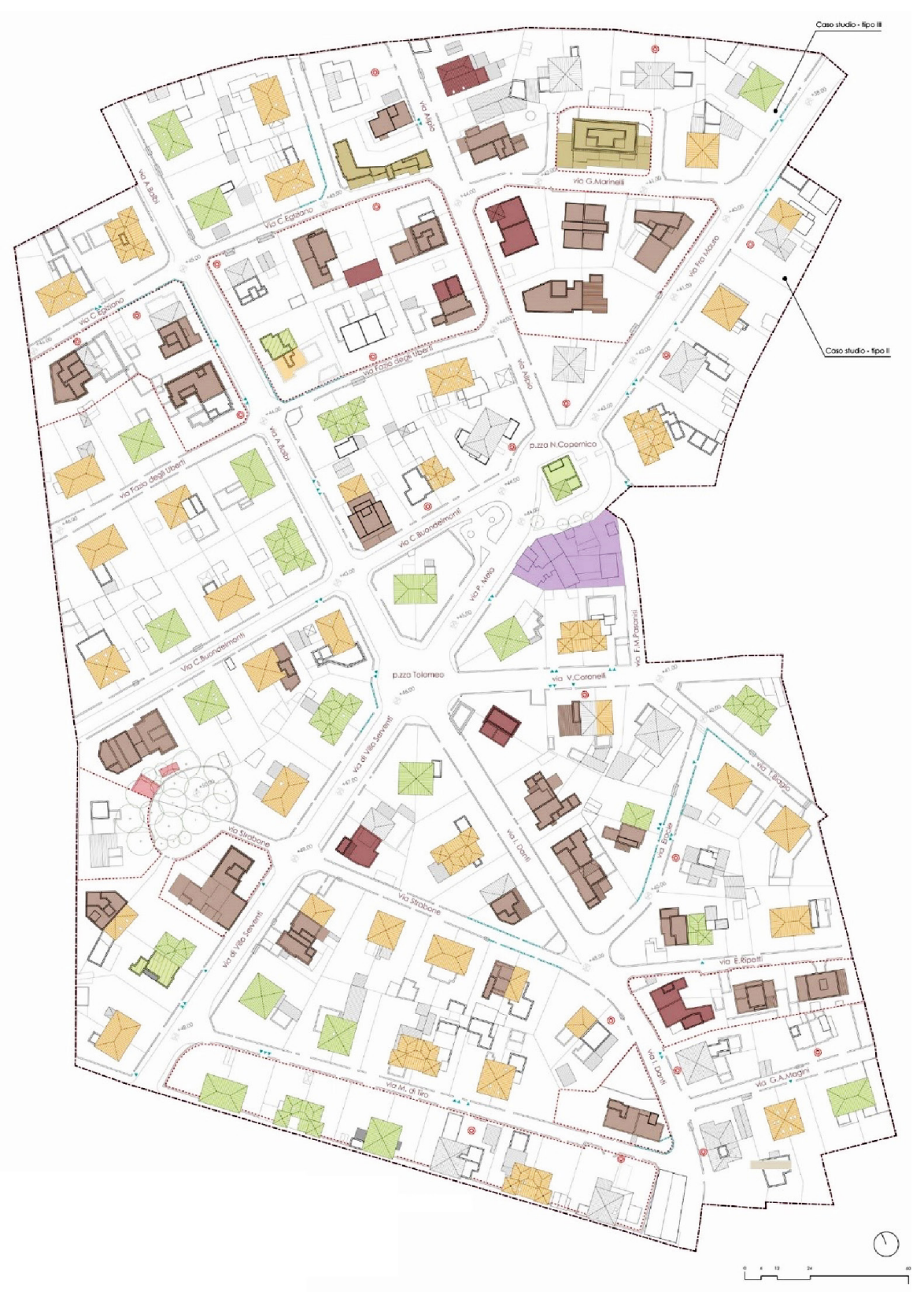


Fig. 10. Photomosaic

modifications of the villini

in the garden borough of

in the garden borough of
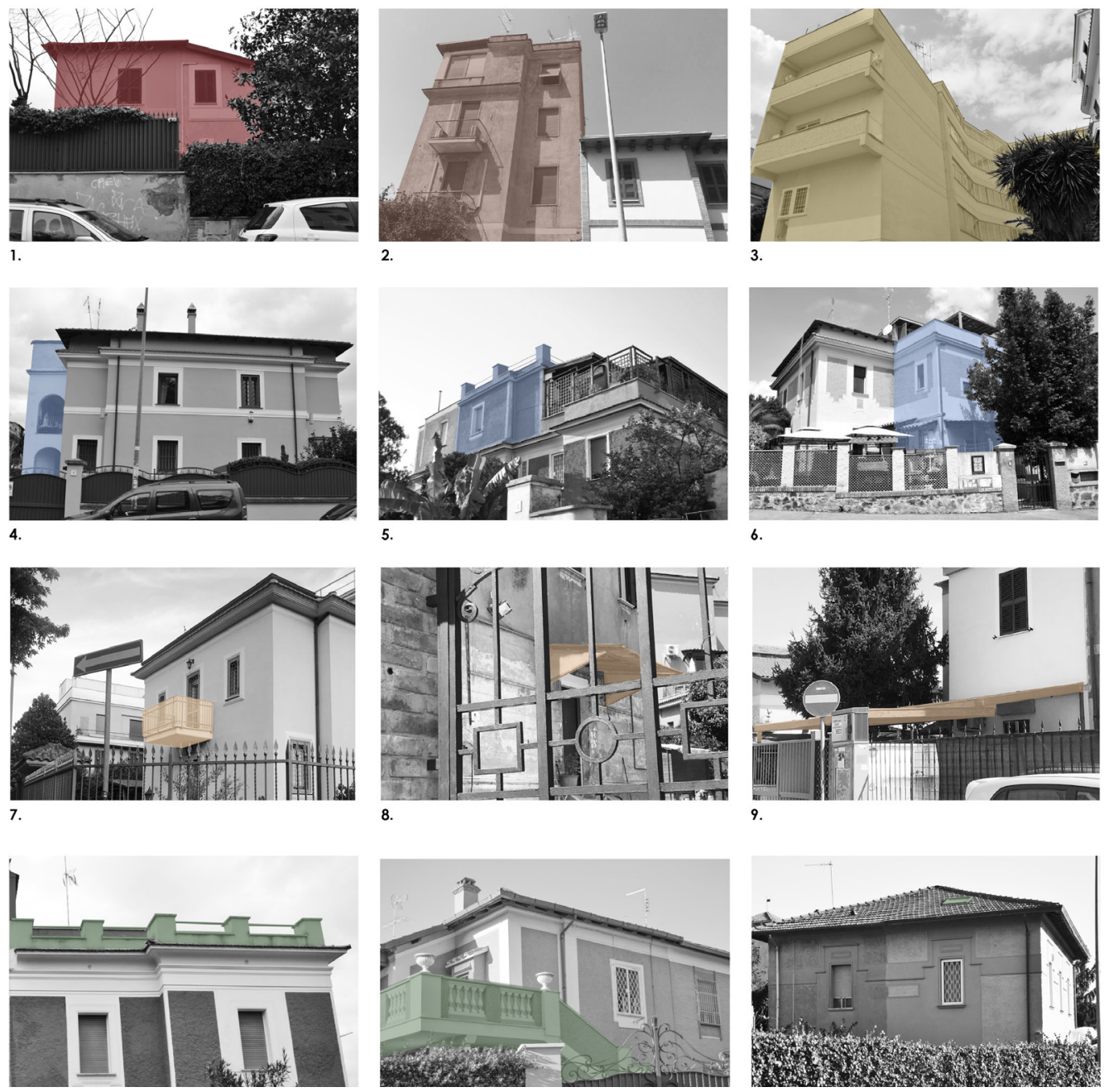

Fig. 11. Survey of the state of decay of one of

the villini in the garden

borough of Pigneto

(graphic elaboration by

V. Apostoli).
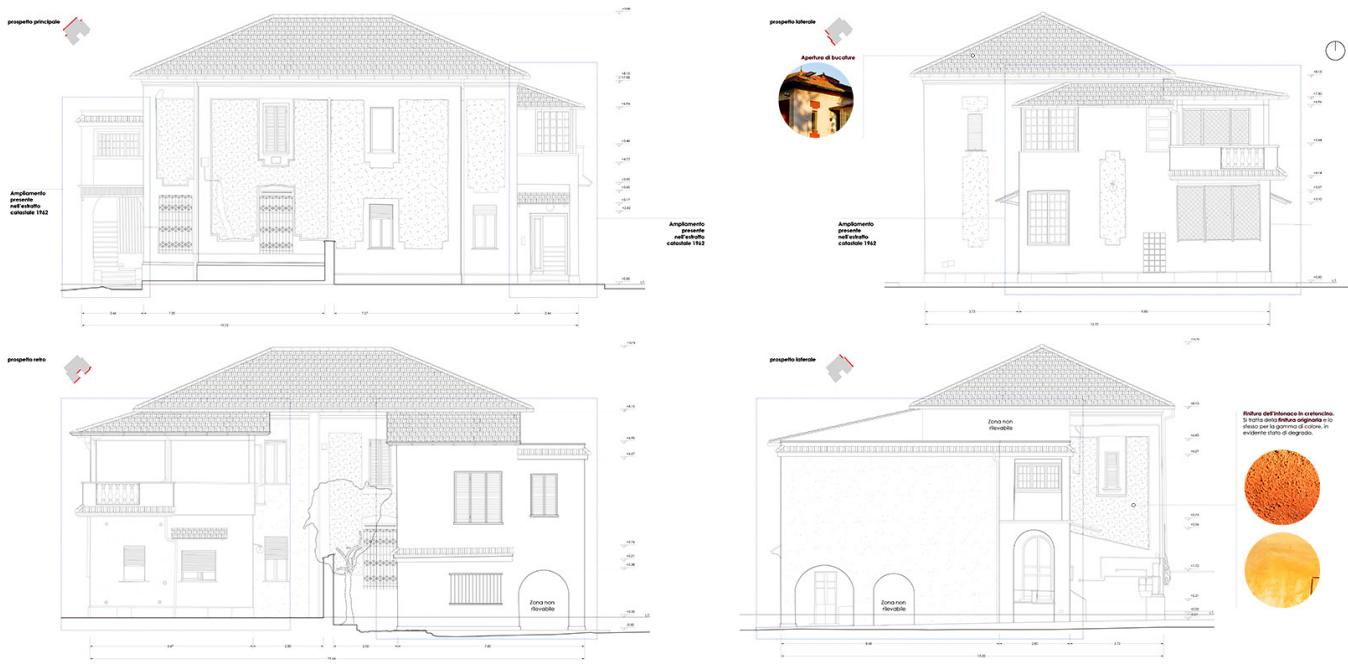


\section{Conclusions}

This study has made it possible to identify the settlement, typological, and architectural characteristics of Pigneto and reconstruct an urban and construction history representative of the Rome of the twentieth century. In fact, the nuclei of small villini built in Pigneto, just as those in Monteverde, Garbatella, or Montesacro, for the city constitute an important architectural heritage to be protected. In this sense, a comparison between past and present aims to lay the foundations for a possible recovery project of the garden borough, starting with a methodological course of survey and historical reconstruction of the area which can relate from the current state the historical memory of the 1920s of the garden borough, together with that of the 1960s, narrated by Pasolini. Two apparently distant historical phases brought together through a trasversal-reading allow us to reinterpret their affinities and similarities. In recent years, as touched on, the interaction with the city's historic center, the vitality that characterizes the Pigneto, and the artistic contamination that identifies the image of the borough, attracts more and more people and the garden borough, although still recognizable, risks losing many of its particulars that should instead be safeguarded and promoted.
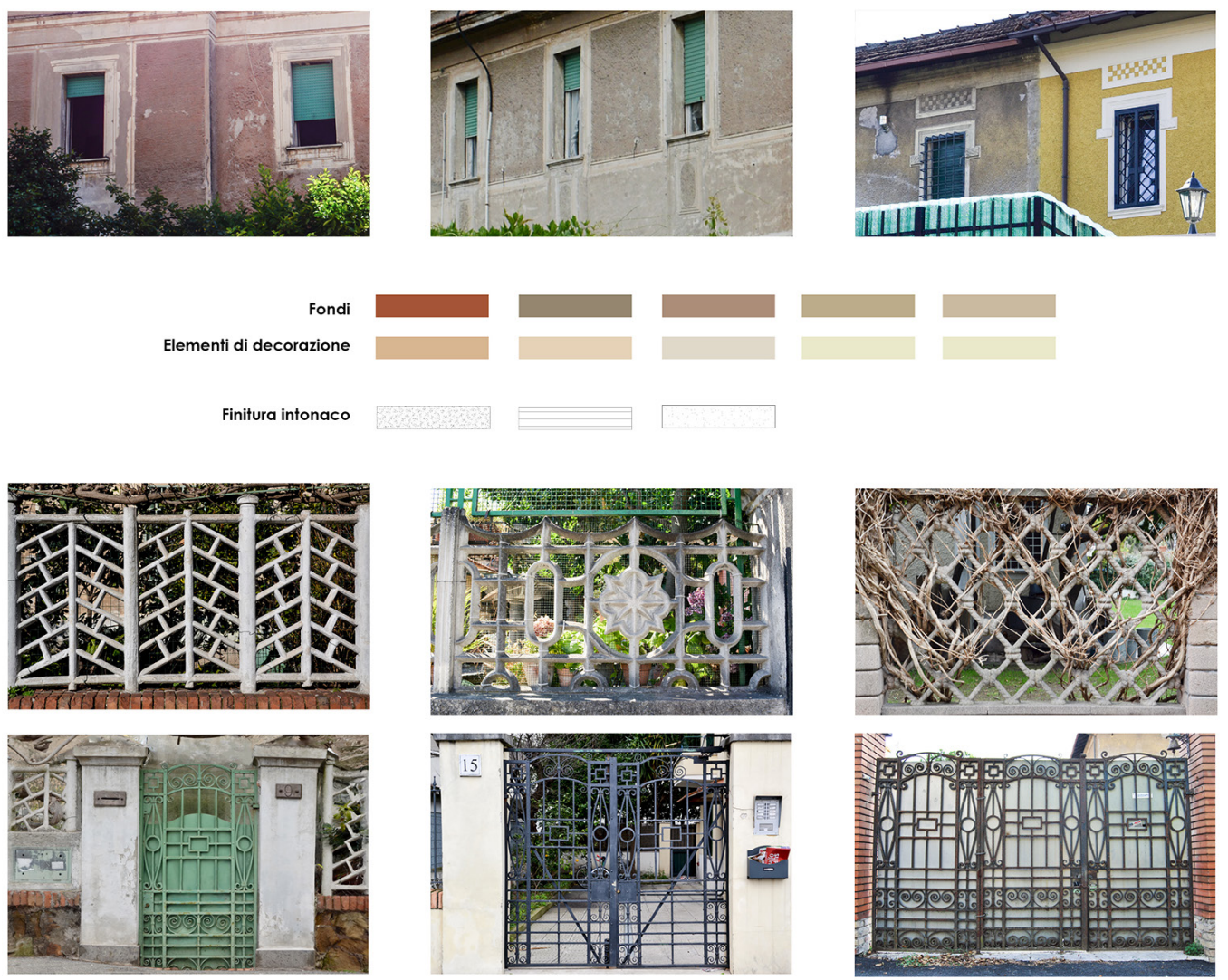

\section{Notes}

[I] From the stills of the video acquired from the GoogleEarth model it was possible to obtain a 3D model of the area being examined, using the SFM (Structure from Motion) photogrammetric rendering method and the Metashape program. See: Canciani, Fioravanti 2019; Chen, Clarke 2016.

[2] Accattone, movie written and directed by Pier Paolo Pasolini (1961), cast: Sandro Citti, Franca Pasut, Silvana Corsini, Paola Guidi, Adriana Asti.

[3] Uno scrittore e un luogo: Pasolini e il Pigneto, from ansa.it website: <https://www.ansa.it/lifestyle/notizie/people/storie/20 I 4/07/3 I/uno-scrittore-e-un-luogo-pierpaolo-pasolini-e-il-pigneto> (accessed on 202I January 2I). 
[4] The 1977 variation of the PRG reclassified Pigneto from C zone - Road and building resizing (for substantial expansion), to B for the conservation of the building fabric. See: Severino 2005, p. 199.

[5] 'Gentrification' is the phenomenon of urban regeneration of some peripheral boroughs leadings to an exponential increase in housing prices with the consequent migration of the original inhabitants to other, cheaper urban areas.

[6] G. Giovannoni, Relazione della Commissione Tecnica del 1919 del Comitato Centrale Edilizio per la costruzione di case popolari in Roma, Centro di Studi per la Storia dell'Architettura, Roma, Fondo Giovannoni.

[7] Archivio Storico Cooperativa Termini, Roma, Libro dei Verbali del Consiglio, meeting August 7, 1920, p. 84.

\section{References}

Apostoli V. (2019). La Cooperativa Termini al Pigneto 1919-1930. Storia, rilievo e conservazione. Tesi di laurea Magistrale in Architettura-Restauro. Relatori M. Canciani, F.R. Stabile. Dipartimento di Architettura, Università degli Studi Roma Tre.

Bartolini F. (200I). Roma borghese: la casa e i ceti medi tra le due guerre. Roma-Bari: Laterza.

Benevolo L. (1992). Roma dal 1870 al 1990. Roma-Bari: Laterza.

Boldi M.A. (1910). Le Case Popolari. Milano: Hoepli.

Brunori G., Cretarola A., Zampilli M. (20 I 6). Tivoli: lettura di una città. In U+D urbanform and design, n. 05/06, pp. 32-49.

C. G. (1925). Edilizia in Roma. In Capitolium, I, n. I, pp. 44-49.

Canciani M., Sturm S., G. Fioravanti (2020). Il cielo sopra Foligno. Rilievo 3D del centro storico tramite tecnologia aeromobile a pilotaggio remoto (APR). In Sturm S. (a cura di). Foligno. I palazzi e la città dal Rinascimento al Neoclassico. Perugia: Quattroemme.

Canciani M., et al. (2019). Cartografia aggiornata del centro storico di Tivoli: contributi al GIS del territorio del Comune. In Martines R., Pallottino E. (a cura di). Tivoli, un laboratorio urbano. leri, oggi, domani. Roma: Edizioni Roma TrE-Press, pp. 97 - I26.

Casali I. (1909). Tipi originali di casette popolari e villini economici. Milano: Hoepli.

Chen J., Clarke K. (2016). Rapid 3D Modeling Using Photogrammetry Applied to Google Earth. In Proceedings, Autocarto 2016 . The 2 Ist International Research Symposium on Computer-Based Cartography and GIScience. Albuquerque, New Mexico, pp. 14-27.

Giovannoni G. [1919]. Relazione della Commissione Tecnica del 1919 del Comitato Centrale Edilizio per la costruzione di case popolari in Roma. Centro di Studi per la Storia dell'Architettura, Roma, Fondo Giovannoni.

Kraus K., (2007). Photogrammetry: Geometry from Images and Laser Scans. Berlino: De Gruyter Textbook.

Magliaro A. (20 I 4). Uno scrittore e un luogo: Pasolini e il Pigneto <https://www.ansa.it/lifestyle/notizie/people/storie/20 I 4/07/3 I/ uno-scrittore-e-un-luogo-pierpaolo-pasolini-e-il-pigneto> (accessed 2021, January 20).

Pasolini P.P. (1955). Ragazzi di vita. Milano: Garzanti.

Remondino F., El-Hakim S. (2006). Image-based 3D modelling: a review. In The Photogrammetric Record, vol. 2 I (I I 5), pp. 269-29l.

Schiavi A. (|9| I). Le case a buon mercato e le città giardino. Bologna: Zanichelli.

Severino C.G. (2005). Roma mosaico urbano: il Pigneto fuori Porta Maggiore. Roma: Gangemi.

Stabile F.R. (2019). La Garbatella a Roma. Architettura e regionalismo. Roma: Quasar.

\section{Authors}

Marco Canciani, Università degli Studi RomaTre, marco.canciani@uniroma3.it

Francesca Romana Stabile, Università degli Studi RomaTre, francescaromana.stabile@uniroma3.it

Valentina Apostoli, Università degli Studi RomaTre, apostolivalentina@gmail.com

To cite this chapter. Canciani Marco, Stabile Francesca Romana, Apostoli Valentina (2021). Linguaggi architettonici tra presente e passato: la borgata giardino del Pigneto/Architectural languages between past and present: the city garden of Pigneto. In Arena A., Arena M., Mediati D., Raffa P. (a cura di). Connettere. Un disegno per annodare e tessere. Linguaggi Distanze Tecnologie. Atti del $42^{\circ}$ Convegno Internazionale dei Docenti delle Discipline della Rappresentazione/Connecting. Drawing for weaving relationship. Languages Distances Technologies. Proceedings of the $42^{\text {th }}$ International Conference of Representation Disciplines Teachers. Milano: FrancoAngeli, 307-328. 